\title{
Plateaus and jumps in the atmospheric radiocarbon record - potential origin and value as global age markers for glacial-to-deglacial paleoceanography, a synthesis
}

\author{
Michael Sarnthein ${ }^{1}$, Kevin Küssner ${ }^{2}$, Pieter M. Grootes ${ }^{3}$, Blanca Ausin ${ }^{4,8}$, Timothy Eglinton ${ }^{8}$, Juan Muglia ${ }^{5}$, \\ Raimund Muscheler $^{6}$, and Gordon Schlolaut ${ }^{7}$ \\ ${ }^{1}$ Institute of Geosciences, University of Kiel, Olshausenstr. 40, 24098 Kiel, Germany \\ ${ }^{2}$ Alfred-Wegener-Institut Helmholtz-Zentrum für Polar- und Meeresforschung, Department for Marine Geology, \\ 27570 Bremerhaven, Germany \\ ${ }^{3}$ Institute of Ecosystem Research, University of Kiel, Olshausenstr. 40, 24098 Kiel, Germany \\ ${ }^{4}$ Geology Department, University of Salamanca, Plaza de los Caldos, 37008 Salamanca, Spain \\ ${ }^{5}$ Centro para el Estudio de los Sistemas Marinos, CONICET, 2915 Boulevard Brown, U9120ACD, Puerto Madryn, Argentina \\ ${ }^{6}$ Quaternary Sciences, Department of Geology Lund University, Sölvegatan 12, 22362 Lund, Sweden \\ ${ }^{7}$ Climate Dynamics and Landscape Evolution, GFZ German Centre for Geosciences, \\ Telegrafenberg, 14473 Potsdam, Germany \\ ${ }^{8}$ Geological Institute, ETH Zürich, Sonneggstr. 5, 8092 Zurich, Switzerland
}

Correspondence: Michael Sarnthein (michael.sarnthein@ifg.uni-kiel.de)

Received: 9 October 2019 - Discussion started: 25 October 2019

Revised: 7 August 2020 - Accepted: 16 November 2020 - Published: 23 December 2020

\begin{abstract}
Changes in the geometry of ocean meridional overturning circulation (MOC) are crucial in controlling past changes of climate and the carbon inventory of the atmosphere. However, the accurate timing and global correlation of short-term glacial-to-deglacial changes of MOC in different ocean basins still present a major challenge. The fine structure of jumps and plateaus in atmospheric and planktic radiocarbon $\left({ }^{14} \mathrm{C}\right)$ concentration reflects changes in atmospheric ${ }^{14} \mathrm{C}$ production, ocean-atmosphere ${ }^{14} \mathrm{C}$ exchange, and ocean mixing. Plateau boundaries in the atmospheric ${ }^{14} \mathrm{C}$ record of Lake Suigetsu, now tied to Hulu Cave U/Th model ages instead of optical varve counts, provide a stratigraphic "rung ladder" of up to 30 age tie points from 29 to 10 cal ka for accurate dating of planktic oceanic ${ }^{14} \mathrm{C}$ records. The age differences between contemporary planktic and atmospheric ${ }^{14} \mathrm{C}$ plateaus record the global distribution of ${ }^{14} \mathrm{C}$ reservoir ages for surface waters of the Last Glacial Maximum (LGM) and deglacial Heinrich Stadial 1 (HS-1), as documented in 19 and 20 planktic ${ }^{14} \mathrm{C}$ records, respectively. Elevated and variable reservoir ages mark both upwelling regions and highlatitude sites covered by sea ice and/or meltwater. ${ }^{14} \mathrm{C}$ venti-
\end{abstract}

lation ages of LGM deep waters reveal opposed geometries of Atlantic and Pacific MOC. Like today, Atlantic deep-water formation went along with an estuarine inflow of old abyssal waters from the Southern Ocean up to the northern North Pacific and an outflow of upper deep waters. During early HS-1, ${ }^{14} \mathrm{C}$ ventilation ages suggest a reversed MOC and $\sim 1500$ year flushing of the deep North Pacific up to the South China Sea, when estuarine circulation geometry marked the North Atlantic, gradually starting near $19 \mathrm{ka}$. High ${ }^{14} \mathrm{C}$ ventilation ages of LGM deep waters reflect a major drawdown of carbon from the atmosphere. The subsequent major deglacial age drop reflects changes in MOC accompanied by massive carbon releases to the atmosphere as recorded in Antarctic ice cores. These new features of MOC and the carbon cycle provide detailed evidence in space and time to test and refine ocean models that, in part because of insufficient spatial model resolution and reference data, still poorly reproduce our data sets. 


\section{Introduction}

\subsection{A variety of terms linked to the notion " ${ }^{14} \mathrm{C}$ age"}

The ${ }^{14} \mathrm{C}$ concentration in the troposphere is mainly determined by ${ }^{14} \mathrm{C}$ production, atmospheric mixing, air-sea gas exchange, and ocean circulation, which vary over time (e.g., Alves et al., 2018; Alveson, 2018). The ${ }^{14} \mathrm{C}$ content of living terrestrial plants is in equilibrium with the atmosphere via processes of photosynthesis and respiration. Accordingly, the ${ }^{14} \mathrm{C}$ of terrestrial plant remains in a sediment section directly reflects the amount of radioactive decay, and thus the time passed since the plant's death and the ${ }^{14} \mathrm{C}$ composition of the atmosphere during the time of plant growth.

In contrast, ${ }^{14} \mathrm{C}$ values of marine and inland waters are cut off from cosmogenic ${ }^{14} \mathrm{C}$ production in the atmosphere, and hence depend on the carbon transfer at the air-water interface and the result of local transport and mixing of carbon in the water. For surface waters, the air-sea transfer involves a time span of 10 years or less (e.g., Nydal et al., 1980). However, vertical and horizontal water mixing results in surface ocean ${ }^{14} \mathrm{C}$ concentrations that are on average $5 \%$ lower than those in the contemporaneous atmosphere, a difference expressed as "Marine Reservoir Age" (or "reservoir effect", sensu Alves et al., 2018). These "ages" reflect the local oceanography and are highly variable through time ( 200-2500 years; e.g., Stuiver and Braziunas, 1993; Grootes and Sarnthein, 2006; Sarnthein et al., 2015). Apart from U/Th dated corals (many papers have been published on their reservoir age since Adkins and Boyle, 1997), the ${ }^{14} \mathrm{C}$ age of planktic foraminifers is the most common tracer in marine sediments, providing a rough estimate of the time passed since sediment deposition. Soon after, however, marine geologists were confronted with age inconsistencies that implied a series of unknowns, in particular the surface ocean ${ }^{14} \mathrm{C}$ "reservoir age" that finally became a most valuable tracer for oceanography.

The ${ }^{14} \mathrm{C}$ records of benthic foraminifers in deep-sea sediments reflect the time of radioactive decay since their deposition with the apparent "ventilation age" of the deep waters in which they lived. Ventilation age is primarily the time span from the moment when carbon dissolved in the local surface waters with a somewhat reduced ${ }^{14} \mathrm{C}$ level lost contact with the atmosphere until the precipitation of benthic carbonate from the down-welled deep waters. Details on the derivation of ventilation ages are provided in Cook and Keigwin (2015) and Balmer and Sarnthein (2018). In addition, however, ventilation ages include difficult to quantify lateral admixtures of older and/or younger water masses, as well as ${ }^{14} \mathrm{C}$-enriched organic carbon supplied by the biological pump, and are thus referred to as "apparent". Today, the apparent transit times of carbon dissolved in the deep ocean range from a few hundred up to the $\sim 1800{ }^{14} \mathrm{C}$ years found in upper deep waters of the northeastern North Pacific (Matsumoto, 2007).
The reservoir ages of surface waters and the ventilation ages of deep waters present robust and high-resolution tracers essential for drawing quantitative conclusions on past ocean circulation geometries, marine climate change, and the processes that drive both past ocean dynamics and carbon budgets, given that the ages rely on a number of robust age tie points. Obtaining such tie points presents a problem, since any attempt to date a deep-sea sediment record by means of ${ }^{14} \mathrm{C}$ encounters a number of intricacies of how to disentangle the effects of global atmospheric ${ }^{14} \mathrm{C}$ variations due to past changes in cosmogenic ${ }^{14} \mathrm{C}$ production and carbon cycle from (i) local depositional effects such as sediment hiatuses and winnowing, differential bioturbational mixing depths, and sediment transport by deep burrows; (ii) the effects of local atmosphere-ocean exchange and ocean mixing, resulting in reservoir and ventilation ages that change through time and space (e.g., Alves et al., 2018; Grootes and Sarnthein, 2006); and (iii) quantitatively "pure" ${ }^{14} \mathrm{C}$ ages due to radioactive decay from the final target. These problems are exacerbated by the need for a generally accepted high-precision atmospheric reference record for the period $14-50 \mathrm{cal} \mathrm{ka}$, which is beyond tree ring calibration.

Current ${ }^{14} \mathrm{C}$-based chronologies of deep-sea sediment records, used to constrain and correlate the age of glacial-todeglacial changes in ocean dynamics and climate on a global scale, are often of insufficient quality when they are (i) based on age tie points that are spaced far too widely (e.g., using Dansgaard Oeschger (DO) events 1, 2, and 3 only and/or sporadic tephra layers for the time span $30-14 \mathrm{cal} \mathrm{ka}$ ), (ii) disregarding atmospheric ${ }^{14} \mathrm{C}$ plateaus, (iii) making the risky assumption of \pm constant planktic ${ }^{14} \mathrm{C}$ reservoir ages and other speculative stratigraphic correlations or compilations, and (iv) ignoring small-scale major differences in low-latitude reservoir age. Likewise, clear conclusions are precluded by an uncertainty range of 3-4 kyr that is sometimes accepted for tie points during the glacial-to-deglacial period (Stern and Lisiecki, 2013; Lisiecki and Stern, 2016), where significant global climate oscillations occurred on decadal-to-centennial timescales, as widely shown on the basis of speleothem and ice-core-based records (Steffensen et al., 2008; Svensson et al., 2008; Wang et al., 2001). Thus, marine paleoclimate and paleoceanographic studies today focus on the continuing quest for a high-resolution and global (and thus necessarily atmospheric) ${ }^{14} \mathrm{C}$ reference record.

\subsection{Review of tie points used to fix calibrated and reservoir ages in marine ${ }^{14} \mathrm{C}$ records}

The tree-ring-based calibration of ${ }^{14} \mathrm{C}$ ages provides a master record of decadal changes in atmospheric ${ }^{14} \mathrm{C}$ concentrations back to $\sim 14$ cal ka (Reimer et al., 2013, 2020) with floating sections beyond (from $\sim 12.5-14.5$, around 29-31.5, and 43 cal ka; Turney et al., 2010, 2017; Reimer et al., 2020). The evolution of Holocene and late deglacial ${ }^{14} \mathrm{C}$ ages with time is not linear but reveals variations with numerous dis- 
tinct jumps (i.e., rapid change) and (short) plateau-shaped (slow or no change or even inversion) structures indicative of fluctuations in atmospheric ${ }^{14} \mathrm{C}$ concentration. Prior to $8500 \mathrm{BP}$, various plateaus extend over 400-600 cal year (yr) and beyond (Fig. 2). Given the quality of the tree ring calibration data, these fluctuations can be considered real and suitable for global correlation (Sarnthein et al., 2007, 2015; Umling and Thunnell, 2017; Sarnthein and Werner, 2018). Air-sea gas exchange transfers the atmospheric ${ }^{14} \mathrm{C}$ fluctuations into the surface ocean, where they can provide high-resolution tie points to calibrate the marine ${ }^{14} \mathrm{C}$ record and marine reservoir ages back to $\sim 14 \mathrm{ka}$ (via " ${ }^{14} \mathrm{C}$ wiggle matching"). In the near future, however, it is unlikely that a continuous tree-ring-based record will become available to trace such atmospheric ${ }^{14} \mathrm{C}$ variations further back over the period 14-29 cal ka crucial for the understanding of last-glacial-to-interglacial changes in climate. Hence, various other carbonate-based ${ }^{14} \mathrm{C}$ archives have been employed for this period to reconstruct past changes in atmospheric ${ }^{14} \mathrm{C}$ concentration and age and tie them to an "absolute" or "calibrated" (e.g., incremental and/or based on speleothem carbonate) age scale.

Suites of ${ }^{14} \mathrm{C}$ ages of paired marine and terrestrial plantborne samples, e.g., paired planktic foraminifers and wood chunks, provide the most effective but rarely realizable absolute-age markers and reservoir ages of local ocean surface waters (Zhao and Keigwin, 2018; Rafter et al., 2018; Schroeder et al., 2016; Broecker et al., 2004). Likewise, the alignment of ${ }^{14} \mathrm{C}$-dated variations in downcore seasurface temperatures (SST) with changes in hydroclimate as recorded in age-calibrated sedimentary leaf-wax hydrogen isotope $(\delta \mathrm{D})$ records from ancient lakes (Muschitiello et al., 2019) appears to be successful and is assumed to be coeval. Further tie points are derived from volcanic ash layers (Waelbroeck et al., 2001; Siani et al, 2013; Davies et al., 2014; Sikes and Guilderson, 2016), paired U/Th- and ${ }^{14} \mathrm{C}$-based coral ages (Adkins and Boyle, 1997; Robinson et al., 2005; Burke and Robinson, 2012; Chen et al., 2015), and the (fairly fragmentary) alignment of major tipping points in ${ }^{14} \mathrm{C}$ dated records of marine SST and planktic $\delta{ }^{18} \mathrm{O}$ to the incremental age scale of climate events dated in polar ice core records (Waelbroeck et al., 2011). Such well-defined tie points, however, are spaced widely in peak glacial to early deglacial ice core records and too widely to properly resolve a clear picture of the spatiotemporal pattern of marine paleoclimate events. Finally, various data compilations tentatively rely on the use of multiple age correlations amongst likewise poorly dated marine sediment records, an effort that is necessarily problematic. Skinner et al. (2019) recently combined new and existing reservoir age estimates from North Atlantic and Southern Ocean to show coherent but distinct regional reservoir age trends in subpolar ocean regions, trends that indeed envelop the range of actual major small-scale and shortterm oscillations in reservoir age revealed by our technique of ${ }^{14} \mathrm{C}$ plateau tuning for the subpolar South Pacific (Küssner et al., 2020a).

Lacking robust age tie points, several authors resort to ${ }^{14} \mathrm{C}$ reservoir age simulations for various sea regions by ocean General Circulation Models (GCMs) (e.g. Butzin et al., 2017; Muglia et al., 2018) to quantify the potential difference between marine and atmospheric ${ }^{14} \mathrm{C}$ dates for glacialto-interglacial periods. In view of the complexity of ocean Meridional Overturning Circulation (MOC) and the global carbon cycle, it is not surprising that the results of a comparison of a selection of robust empiric vs. simulated ${ }^{14} \mathrm{C}$ reservoir ages are not that encouraging yet (as discussed further below).

Beyond accepting a generally close link between ${ }^{14} \mathrm{C}$ concentrations in the troposphere and in the surface ocean, the fine structure of planktic ${ }^{14} \mathrm{C}$ records with centennial-scale resolution can provide a far superior (though costly) link from the marine sediment records to the reference suite of narrow-standing jumps and boundaries of the plateaus robustly identified in the atmospheric ${ }^{14} \mathrm{C}$ record of Lake Suigetsu, the only long and continuous record based on terrestrial plant remains (Bronk Ramsey et al., 2012, 2020). Beyond the reach of the tree-ring-based age scale $\sim 14$ cal ka, the absolute age of the Suigetsu atmospheric ${ }^{14} \mathrm{C}$ structures can be either calibrated by incremental (microscopyor XRF-based) varve counts (Schlolaut et al., 2018; Marshall et al., 2012) or by a series of paired U/Th- and ${ }^{14} \mathrm{C}$-based model ages correlated from the Hulu Cave speleothem record (Bronk Ramsey, 2012, 2020; Southon et al., 2012; Cheng et al., 2018). The difference in absolute age between these calibrations (Fig. 3) is of little importance for the tuning of planktic plateaus to corresponding atmospheric ${ }^{14} \mathrm{C}$ plateaus and the derivation of planktic reservoir ages that present the highly variable offset of the ${ }^{14} \mathrm{C}$ age of a planktic plateau from that of the correlated atmospheric plateau. The offset is deduced by subtracting the average ${ }^{14} \mathrm{C}$ age of an atmospheric ${ }^{14} \mathrm{C}$ plateau from that of the correlated planktic ${ }^{14} \mathrm{C}$ plateau, independent of any absolute age value assigned.

The uncertainty of the Suigetsu atmospheric ${ }^{14} \mathrm{C}$ record is significantly larger than that of the tree ring-based calibration record because of lower $14 \mathrm{C}$ concentrations, limited sampling density, and uncertainties in the independent age determination. Thus the ${ }^{14} \mathrm{C}$ fluctuations could be real or represent mere statistical scatter (null hypothesis) in which case the record of atmospheric ${ }^{14} \mathrm{C}$ ages against time would show a simple continuous rise resulting from radioactive decay and the advance of time, such as is suggested by a fairly straight progression of the highly resolved deglacial Hulu Cave ${ }^{14} \mathrm{C}$ record plotted vs. U/Th ages (Southon et al., 2012; Cheng et al., 2018).

The unequivocal fluctuations in the tree-ring-based master record of atmospheric ${ }^{14} \mathrm{C}$ concentration (Fig. 2; Reimer et al., 2013, 2020) are on the order of $2 \%-3 \%$ over the last $10 \mathrm{kyr}$ (Stuiver and Braziunas, 1993) and even larger back to $\sim 14 \mathrm{ka}$. Under glacial and deglacial low- $\mathrm{CO}_{2}$ conditions be- 
yond $14 \mathrm{ka}$, when climate and ocean dynamics were less constant than during the Holocene, real atmospheric ${ }^{14} \mathrm{C}$ fluctuations were, most likely, even stronger and ${ }^{14} \mathrm{C}$ plateaus and jumps were accordingly larger. Plateau-jump structures are also becoming increasingly evident in the evolving atmospheric calibration record (Reimer et al., 2020). The agedefined plateaus and jumps in the Suigetsu atmospheric ${ }^{14} \mathrm{C}$ calibration curve may thus be regarded as a suite of "real" structures, extending the calibration provided by the tree ring record for the Holocene and Bølling-Allerød-to-Early Holocene periods (Fig. 2) into the early deglacial and Last Glacial Maximum (LGM) periods.

The plateau-jump structures may partly be linked to changes in cosmogenic ${ }^{14} \mathrm{C}$ production, as possibly shown in the ${ }^{10} \mathrm{Be}$ record (Fig. 4; based on data of Adolphi et al., 2018), and are presumably more dominant than shortterm changes in ocean mixing and the carbon exchange between the ocean and the atmosphere. The exchange is crucial, since the carbon reservoir of the ocean contains up to 60 (preindustrial) atmospheric carbon units (Berger and Keir, 1984). The apparent contradiction with the smooth Hulu Cave ${ }^{14} \mathrm{C}$ record (Southon et al., 2012; Cheng et al., 2018) may possibly be explained by the Hulu Cave speleothem precipitation system acting as a low-pass filter for fluctuating atmospheric ${ }^{14} \mathrm{C}$ concentrations (following statistical tests made by Bronk Ramsey et al., 2020) and, to a very limited degree, by the obvious scatter in the Suigetsu data. The filter for Hulu data possibly led to a loss, especially of short-lived structures in the preserved atmospheric ${ }^{14} \mathrm{C}$ record, though some remainders were preserved in the ${ }^{14} \mathrm{C}$ records of Hulu Cave (Fig. 1). So we would rather trust the amplitude of Suigetsu ${ }^{14} \mathrm{C}$ structures than the timing of Hulu Cave data.

Like a "rung ladder", the age-calibrated suite of ${ }^{14} \mathrm{C}$ plateau boundaries and jumps is suited for tracing the calibrated age of numerous plateau boundaries in glacial-todeglacial marine ${ }^{14} \mathrm{C}$ records that are likewise densely sampled, even when some rungs have been destroyed by local influences on gas exchange or ocean mixing. In addition, one may record the average offset of planktic ${ }^{14} \mathrm{C}$ ages from paired atmospheric ${ }^{14} \mathrm{C}$ ages, i.e. the planktic reservoir age, for each single ${ }^{14} \mathrm{C}$ plateau (Sarnthein et al., 2007, 2015). We prefer the Suigetsu record to IntCal20, since it is based on original primary atmospheric data and results in smallscale spatiotemporal changes of reservoir age, whereas IntCal20 mixes and smooths a broad array of different data sources with comparatively coarse age resolution, including carbonate-based speleothem and marine records.

For the first time, this suite of tie points may facilitate a precise temporal correlation of all sorts of changes in surface and deep-water composition on a global scale, crucial for a better understanding of past changes in ocean and climate dynamics.

\subsection{Items discussed in this synthesis}

Section 2 summarizes (1) the means of separating noise and global atmospheric and local oceanic forcings that together control the structure of a planktic ${ }^{14} \mathrm{C}$ plateaus, (2) the choice of a U/Th-based reference timescale (Bronk Ramsey et al., 2012; Cheng et al., 2018) instead of the earlier varvecounted version (Schlolaut et al., 2018) to date the structures in the global atmospheric ${ }^{14} \mathrm{C}$ record of Lake Suigetsu (Sarnthein et al., 2015), (3) the extension of the suite of age tie points back from 23 to $29 \mathrm{cal} \mathrm{ka}$, values crucial for an accurate global correlation of ocean events over the Last Glacial Maximum, and (4) potential linkages of atmospheric ${ }^{14} \mathrm{C}$ plateaus and jumps to cosmogenic ${ }^{14} \mathrm{C}$ production and/or ocean dynamics.

Section 3 includes the following discussions and implications.

1. A global summary of published marine ${ }^{14} \mathrm{C}$ reservoir age records (Sarnthein et al., 2015), now enlarged by nine plateau-tuned records from the Southern Hemisphere (Balmer et al., 2016; Balmer and Sarnthein, 2018; Kuüssner et al., 2018, 2020) and the northeastern Atlantic (Ausin et al., 2020a). In total, 18 (LGM) and 19 Heinrich Stadial 1 (HS-1), plus three wood chunkbased records (Broecker et al., 2004; Zhao et al., 2018), now depict the spatiotemporal variability of past reservoir ages of surface waters in different ocean regions.

2. A comparison of our plateau-based reservoir ages with LGM estimates of surface water ${ }^{14} \mathrm{C}$ reservoir ages simulated by the GCM of Muglia et al. (2018).

3. More detailed insights into the origin of past changes in the global carbon cycle from glacial to interglacial times are provided by the enlarged set of ${ }^{14} \mathrm{C}$ reservoir and ventilation ages that form a robust tracer of global circulation geometries and the inorganic carbon (DIC) dissolved in different basins of the ocean (Sarnthein et al., 2013).

The discussion highlights ${ }^{14} \mathrm{C}$ plateau tuning and its revised calibrated timescale for global data-model intercomparison and a new understanding of ocean MOC during the LGM and its reversal during HS-1.

\section{Results - age tie points based on ${ }^{14} \mathrm{C}$ plateau boundaries}

\subsection{Suite of planktic ${ }^{14} \mathrm{C}$ plateaus: means to separate global atmospheric from local oceanographic forcings}

The basic assumption of the ${ }^{14} \mathrm{C}$ plateau tuning technique is that the fine structure of fluctuations of the global atmospheric ${ }^{14} \mathrm{C}$ concentration record can also be found in the surface ocean. In a plot of ${ }^{14} \mathrm{C}$ age vs. calendar age such 

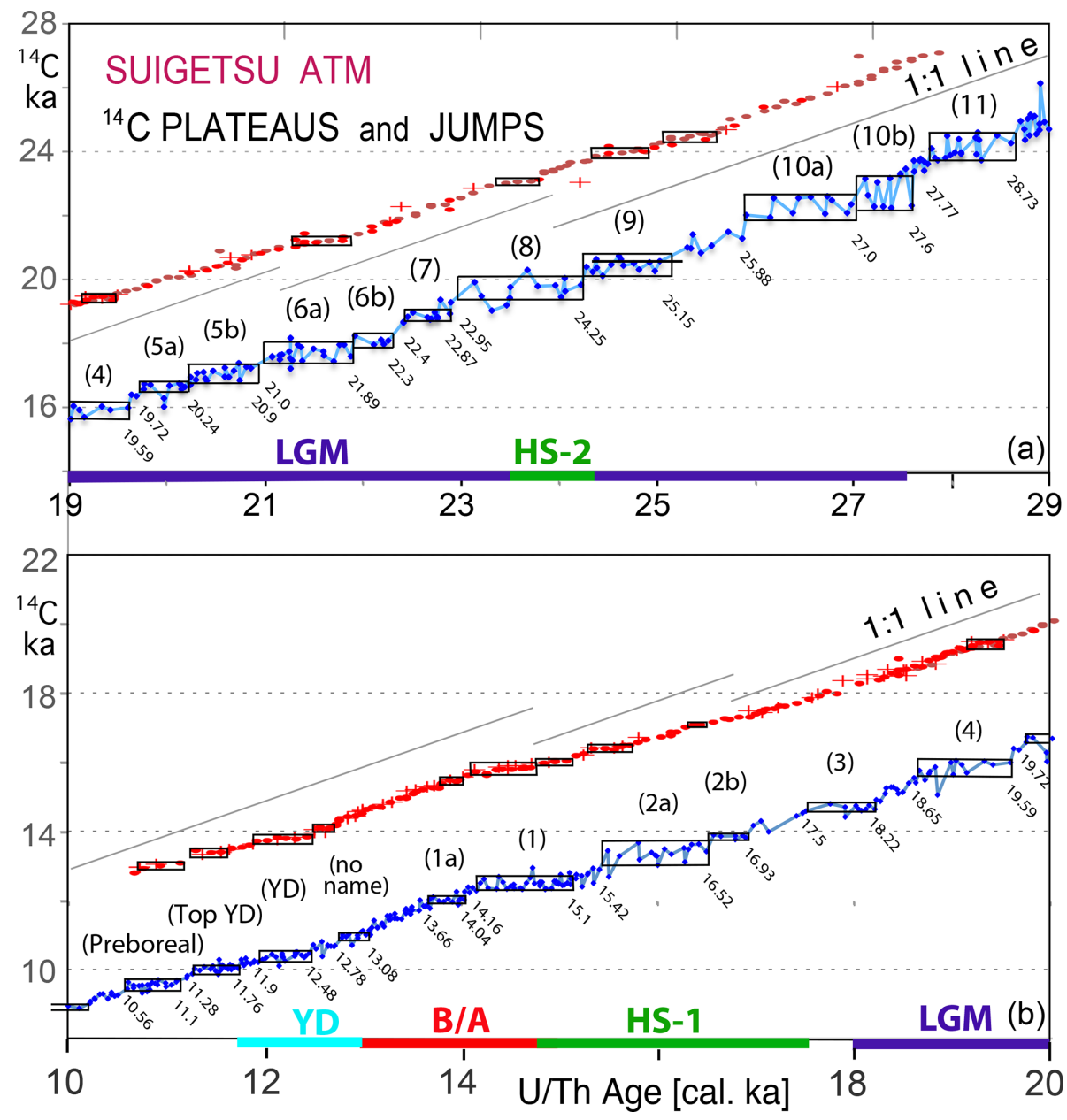

Figure 1. Atmospheric ${ }^{14} \mathrm{C}$ ages of Lake Suigetsu plant macrofossils from 10-20 cal ka (b) and 19-29 cal ka (a) vs. U/Th-based model age (blue dots; Bronk Ramsey et al., 2012). The $1: 1$ line reflects a gradient of $1{ }^{14} \mathrm{C}$ year per 1 cal yr. Double and triple ${ }^{14} \mathrm{C}$ measurements are averaged. Large (in part) error bars of single ${ }^{14} \mathrm{C}$ ages are given in Fig. S1 in the Supplement. A suite of labeled horizontal boxes that envelop scatter bands of largely constant ${ }^{14} \mathrm{C}$ ages shows ${ }^{14} \mathrm{C}$ plateaus longer than 250 years (plateau boundary ages listed in Table 1). Red and brown dots (powder samples from the trench and wall) and + signs (off-axis samples) depict raw ${ }^{14} \mathrm{C}$ ages of Hulu stalagmites $\mathrm{H} 82$ and MSD (Cheng et al., 2018; Southon et al., 2012; plot offset by $+3000{ }^{14} \mathrm{C}$ years). A suite of short ${ }^{14} \mathrm{C}$ plateaus (black boxes) tentatively assigned to Hulu-based record occupies age ranges slightly different from those deduced for Suigetsu-based plateaus. The difference possibly results from short-term changes in the Old or Dead Carbon Fraction (OCF or DCF, respectively) that in turn may reflect major short-term changes in LGM and deglacial monsoon climate (Wang et al., 2001; Kong et al., 2005).

fluctuations lead to a pattern of plateaus and jumps that correspond to decreases and increases in ${ }^{14} \mathrm{C}$ concentration. Here we refer to the derivation and interpretation of planktic ${ }^{14} \mathrm{C}$ plateaus, assuming a predominantly global atmospheric origin with occasional local oceanographic forcings. The series of planktic ${ }^{14} \mathrm{C}$ plateaus and jumps are derived in cores with average hemipelagic sedimentation rates of $>10 \mathrm{~cm} \mathrm{kyr}^{-1}$ and a dating resolution of $<100-150$ years. The plateauspecific structures in a sediment age-depth record form a well-defined suite for which absolute age and reservoir age are derived by means of a strict alignment to the reference suite of global atmospheric ${ }^{14} \mathrm{C}$ plateaus as a whole. Initially, age tie points of planktic foraminiferal ${ }^{18} \mathrm{O}$ records showing (orbital) isotope stages 1-3 serve as stratigraphic guideline for the alignment under the simplifying assumption that stratigraphic gaps are absent, which is not always true (Fig. S2). Planktic reservoir ages and their short-term changes are derived from the difference in average ${ }^{14} \mathrm{C}$ age between atmosphere and surface waters in subsequent plateaus. To stick as close as possible to the modern range of reservoir ages (Stuiver and Braziunas, 1993), tuned reservoir ages are kept at a minimum unless stringent evidence requires otherwise.

A close correspondence between ${ }^{14} \mathrm{C}$ concentrations in atmosphere and surface ocean is expected based on rapid gas exchange. In several cases, however, the specific struc- 
Table 1. Summary of varve- and U/Th model-based age estimates (in cal ka) (Schlolaut et al., 2018; Bronk Ramsey et al., 2012) for 30 plateau (pl.) boundaries in the atmospheric ${ }^{14} \mathrm{C}$ record identified in Lake Suigetsu Core SG06 2012 (composite depth, c.d.) by means of visual inspection over the interval 10.5-27 cal ka (modified from the Supplement to Sarnthein et al., 2015). On the right-hand side, three columns give the average $(\varnothing)$ and uncertainty range of ${ }^{14} \mathrm{C}$ ages for each ${ }^{14} \mathrm{C}$ plateau. YD stands for the Younger Dryas period. Bold and bold-italic fonts mark ages henceforth preferred in this paper; see Sect. 2.2. for more details.

\begin{tabular}{|c|c|c|c|c|c|c|c|c|c|}
\hline \multirow{2}{*}{$\begin{array}{l}\text { Suigetsu } \\
\text { SG06_2012 }\end{array}$} & \multicolumn{3}{|c|}{ Plateau top } & \multicolumn{3}{|c|}{ Plateau base } & \multirow{2}{*}{$\begin{array}{r}\varnothing^{14} \mathrm{C} \text { age } \\
\text { of }{ }^{14} \mathrm{C} \\
\text { Plateau }\end{array}$} & \multirow{2}{*}{$\begin{array}{r} \pm \text { Uncertainty } \\
\left({ }^{14} \mathrm{C} \text { years }\right)\end{array}$} & \multirow{2}{*}{$\begin{array}{r}{ }^{14} \mathrm{C} \text { age } \mathrm{BP} \\
\mathrm{min} / \mathrm{max} \\
(1.6 \sigma \text { range })\end{array}$} \\
\hline & $\begin{array}{l}\text { Varve-based } \\
\text { cal. age } \\
\text { estimates }\end{array}$ & $\begin{array}{l}\text { U/Th-based } \\
\text { cal. age } \\
\text { estimates }\end{array}$ & $\begin{array}{c}\text { Depth } \\
\text { (cm c.d.) }\end{array}$ & $\begin{array}{l}\text { Varve-based } \\
\text { cal. age } \\
\text { estimates }\end{array}$ & $\begin{array}{l}\text { U/Th-based } \\
\text { cal. age } \\
\text { estimates }\end{array}$ & $\begin{array}{l}\text { Depth } \\
\text { (cm c.d.) }\end{array}$ & & & \\
\hline "Preboreal" & 10525 & 10560 & 1325 & 11100 & 11108 & 1383 & 9525 & $-170 /+110$ & $9356 / 9635$ \\
\hline “Top YD” & 11290 & 11281 & 1402 & 11760 & 11755 & 1453 & 10060 & $-100 /+35$ & $9963 / 10095$ \\
\hline "YD” & 11950 & 11895 & 1467 & 12490 & 12475 & 1525 & 10380 & $-170 / 124$ & $10211 / 10504$ \\
\hline "No name" & 12885 & 12780 & 1555 & 13160 & 13080 & 1582 & 11000 & $-85 / 114$ & $10915 / 11114$ \\
\hline 1a & 13580 & 13656 & 1626 & 13980 & 14042 & 1657 & 12006 & 100 & $11857 / 12050$ \\
\hline 1 & 14095 & 14160 & 1666 & 15095 & 15100 & 1740 & 12471 & 185 & $12315 / 12683$ \\
\hline $2 \mathrm{a}$ & 15310 & 15420 & 1754 & 16140 & 16520 & 1802 & 13406 & 245 & $13174 / 13665$ \\
\hline $2 b$ & 16075 & 16520 & 1802 & 16400 & 16930 & 1820 & 13850 & 40 & $13808 / 13885$ \\
\hline 3 & 16835 & 17500 & 1847 & 17500 & 18220 & 1888 & 14671 & 105 & $14582 / 14792$ \\
\hline 4 & 17880 & 18650 & 1913 & 18830 & 19590 & 1971 & 15851 & 190 & $15661 / 16044$ \\
\hline $5 a$ & 18960 & 19720 & 1978 & 19305 & 20240 & 2003 & 16670 & 90 & $16570 / 16750$ \\
\hline $5 b$ & 19305 & 20240 & 2003 & 20000 & 20900 & 2032 & 17007 & 190 & $16830 / 17247$ \\
\hline $6 a$ & 20190 & 21000 & 2050 & 20920 & 21890 & 2105 & 17667 & 262 & $17435 / 17960$ \\
\hline $6 b$ & 20920 & 21890 & 2105 & 21275 & 22300 & 2132 & 18075 & 140 & $17960 / 18240$ \\
\hline 7 & 21375 & 22400 & 2140 & 21790 & 22870 & 2171 & 18843 & 117 & $18741 / 18975$ \\
\hline 8 & 21835 & 22940 & 2175 & 22730 & 24250 & 2257 & 19715 & $-290 / 325$ & $19425 / 20041$ \\
\hline 9 & 22730 & 24250 & 2257 & 23395 & 25150 & 2312 & 20465 & $-227 / 263$ & $20238 / 20728$ \\
\hline $10 \mathrm{a}$ & 23935 & 25880 & 2358 & 25080 & 27000 & 2400 & 22328 & $-380 / 270$ & $21946 / 22600$ \\
\hline $10 \mathrm{~b}$ & 25080 & 27000 & 2400 & 25800 & 27600 & 2426 & 22708 & $-475 / 440$ & $22233 / 23147$ \\
\hline 11 & 26110 & 27770 & 2443 & 27265 & 28730 & 2525 & 24088 & $-360 / 505$ & $23727 / 24595$ \\
\hline
\end{tabular}

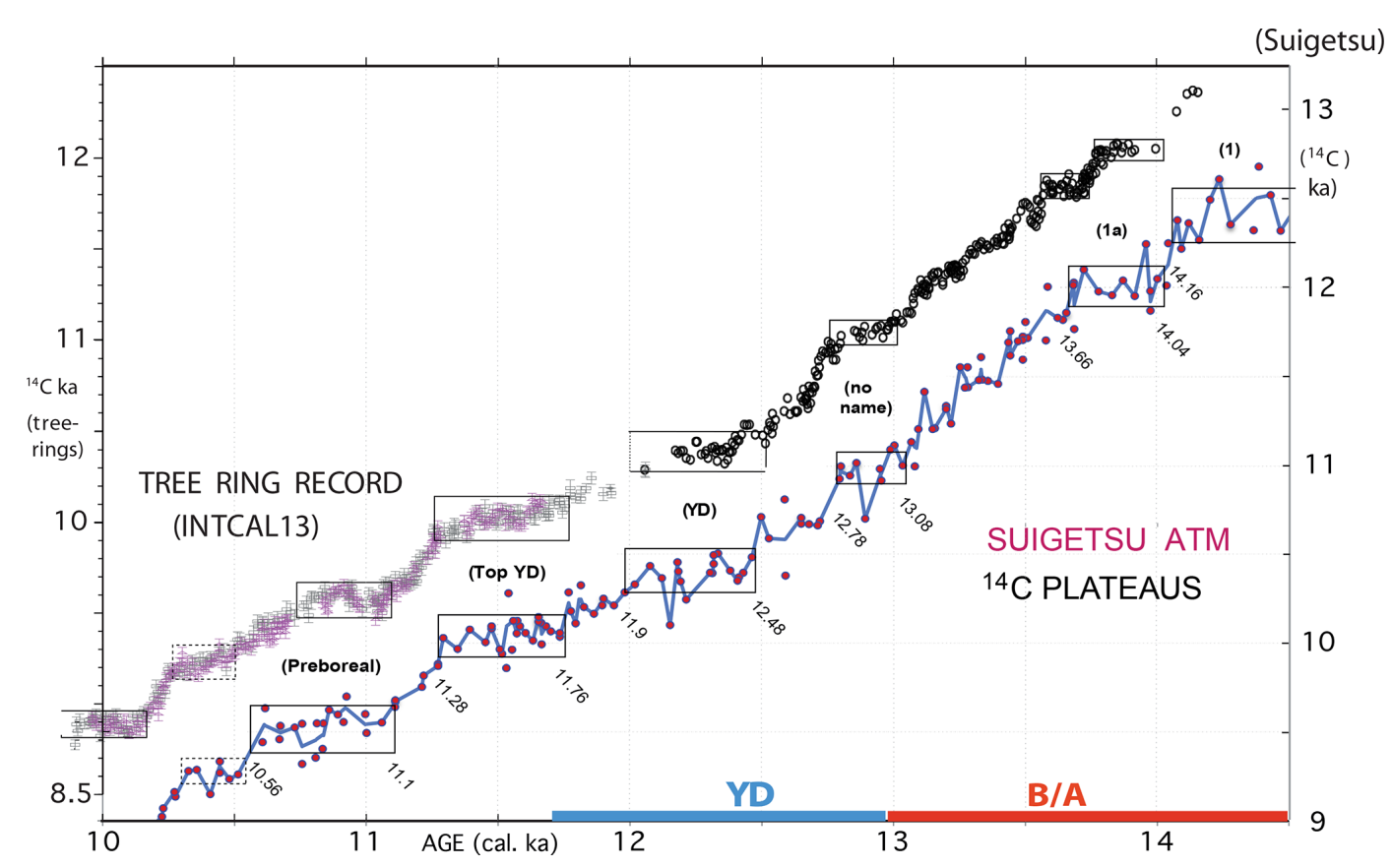

Figure 2. High-resolution record of atmospheric ${ }^{14} \mathrm{C}$ jumps and plateaus (i.e., suite of labeled horizontal boxes that envelop scatter bands of largely constant ${ }^{14} \mathrm{C}$ ages extending over $>300 \mathrm{cal}$ yr) in a sediment section of Lake Suigetsu vs. tree-ring-based ${ }^{14} \mathrm{C}$ jumps and plateaus $10-$ $14.5 \mathrm{cal} k \mathrm{ka}$ (Reimer et al., 2013). The blue line averages paired double and triple ${ }^{14} \mathrm{C}$ ages of Suigetsu plant macrofossils. Age control points (cal ka) follow varve counts (Schlolaut et al., 2018) and U/Th-model-based ages of Bronk Ramsey et al. (2012). YD stands for Younger Dryas, and B/A stands for Bølling-Allerød. 
ture and relative length of a planktic ${ }^{14} \mathrm{C}$ plateau may deviate from those of the pertinent plateau observed within the suite of atmospheric plateaus, and thus indicate local intra-plateau changes of reservoir age. Though less frequent, these changes may indeed amputate and/or deform a plateau, as result of variations in local ocean atmosphere exchange and oceanic mixing. Two aspects help to sort out short-term climate-driven intra- and inter-plateau changes in ${ }^{14} \mathrm{C}$ reservoir age. (i) The evaluation of the structure and reservoir age of an individual plateau strictly includes the age estimates deduced for the complete suite of plateaus. (ii) Our experience shows that deglacial climate regimes in control of changes in surface ocean dynamics generally occurred on (multi-)millennial timescales (e.g., YD, B/A, HS-1), whereas atmospheric ${ }^{14} \mathrm{C}$ plateaus hardly lasted longer than a few hundred up to 1100 years (Figs. 1 and S1). Abrupt changes in gas exchange or ocean mixing usually affect one or only a few plateaus of the suite. Absolute age estimates within a plateau are derived by linear interpolation between the age of the base and top of an undisturbed plateau assuming constant sedimentation rates. The potential impact of short-term sedimentation pulses on ${ }^{14} \mathrm{C}$ plateau formation has largely been discarded by Balmer and Sarnthein (2016).

\subsection{Suigetsu atmospheric ${ }^{14} \mathrm{C}$ record: shift to a chronology based on U/Th model ages}

Originally, we based the chronology of ${ }^{14} \mathrm{C}$ plateau boundaries in the Suigetsu record (Sarnthein et al., 2015) on a scheme of varve counts by means of light microscopy of thin sections (Bronk Ramsey et al., 2012; Schlolaut et al., 2018). Over the crucial sediment sections of the Last Glacial Maximum (LGM) and deglacial Heinrich Stadial 1 (HS-1), however, varve quality and perceptibility in the Suigetsu profile is highly variable (Fig. 5). In parallel, varve-based age estimates were derived from counting various elemental peaks in $\mu \mathrm{XRF}$ data and interpreted as seasonal signals (Marshall et al., 2012). The results obtained from the two independent counting methods and their interpolations widely support each other but diverge for older ages. The varve counts ultimately formed the backbone of a high-resolution chronology obtained by tying the Suigetsu ${ }^{14} \mathrm{C}$ record to the U/Thbased timescale of the Hulu cave ${ }^{14} \mathrm{C}$ record (Bronk Ramsey et al., 2012). Recently, Schlolaut et al. (2018) amended the scheme of varve counts. Accordingly, Suigetsu varve preservation (i.e., the number of siderite layers per $20 \mathrm{~cm}$ thick sediment section) is fairly high prior to $\sim 32 \mathrm{ka}$ and over late glacial Termination I but fairly poor over large parts of the LGM and HS-1, from 15-32 cal ka (17.3-28.5 m c.d. in Fig. 5). Here only fewer than $20 \%-40 \%$ of the annual layers expected from interpolation between clearly varved sections are distinguished by microscopy. Varve counts that use $\mu$ XRF data (Marshall et al., 2012) can distinguish subtle changes in seasonal element variations that are not distinguishable in thin-section microscopy, and hence result in higher varve numbers, especially during early deglacial-topeak glacial times. However, some subtle variations are difficult to distinguish from noise, which adds uncertainty to the $\mu$ XRF-based counts. Thus, the results from either counting method are subject to uncertainties that rise with increased varve age (Fig. 5).

Bronk Ramsey et al. (2012) established a third timescale based on ${ }^{14} \mathrm{C}$ wiggle matching to $\mathrm{U} / \mathrm{Th}$ dated ${ }^{14} \mathrm{C}$ records of the Hulu Cave and Bahamian speleothems. In part, this calibrated (cal.) age scale was based on Suigetsu varve counts, in part on the prerequisite of the best-possible fit of a pattern of low-frequency changes in ${ }^{14} \mathrm{C}$ concentration obtained from Suigetsu and Hulu Cave. The two ${ }^{14} \mathrm{C}$ records were fitted within the uncertainty envelope of the Hulu "Old and Dead Carbon Fraction" (OCF and DCF) of ${ }^{14} \mathrm{C}$ concentration. The uncertainty of this model is still not completely understood. The U/Th-based age model of Suigetsu may suffer from the wiggle matching of atmospheric ${ }^{14} \mathrm{C}$ ages of Lake Suigetsu with ${ }^{14} \mathrm{C}$ ages of the Hulu Cave (Southon et al., 2012) in case of major short-term changes in atmospheric ${ }^{14} \mathrm{C}$ concentration due to a memory effect of soil organic carbon in carbonate-free regions of the cave overburden. The speleothem-carbonate-based Hulu ages may have been influenced far more strongly by short-term changes in the local DCF than assumed, as suggested by major variations in a paired $\delta^{13} \mathrm{C}$ record, that reach up to $5 \%$, mostly subsequent to short-term changes in past monsoon climate (Kong et al., 2005). The uncertainty regarding the assumption of a constant OCF and DCF (Southon et al., 2012; Cheng et al., 2018) may hamper the age model correlation between Hulu and Suigetsu records and the Suigetsu chronology.

We compared the results of the two timescales, which were independently deduced from varve counts, with those of the U/Th-based model age scale using the base of ${ }^{14} \mathrm{C}$ Plateau $2 \mathrm{~b}$ as a test case, which is the oldest tie point constrained by $\mu$ XRF-based counts. In contrast to $16.4 \mathrm{cal} \mathrm{ka}$, proposed by optical varve counts, $\mu$ XRF-based counts suggest an age of $\sim 16.9$ cal ka (Marshall et al., 2012; Schlolaut et al., 2018), which closely matches the U/Th-based estimate of $16.93 \mathrm{ka}$. This is a robust argument for the use of the U/Th-based Suigetsu timescale as it is the "best possible" age scale to calibrate the age of $30{ }^{14} \mathrm{C}$ plateau boundaries (Fig. 1). In its older part, the U/Th model timescale is further corroborated by a decent match of short-term increases in ${ }^{14} \mathrm{C}$ concentration with the low geomagnetic intensity of the Mono Lake and Laschamp events at $\sim 34$ and $41.1 \pm 0.35 \mathrm{ka}$ (Lascu et al., 2016), independently dated by other methods. The new U/Th-based model ages of ${ }^{14} \mathrm{C}$ plateau boundaries are significantly higher than our earlier microscopy-based varve ages over HS- 1 and LGM, a difference increasing from $\sim 200$ years near $15.3 \mathrm{cal}$ ka to $\sim 530$ near $17 \mathrm{ka}$ and 2000 years near $\sim 29 \mathrm{ka}$ (Fig. 3).

Note, any readjustment of the calendar age of a ${ }^{14} \mathrm{C}$ plateau boundary does not entail any change in ${ }^{14} \mathrm{C}$ reservoir ages afore deduced for surface waters by means of the plateau 


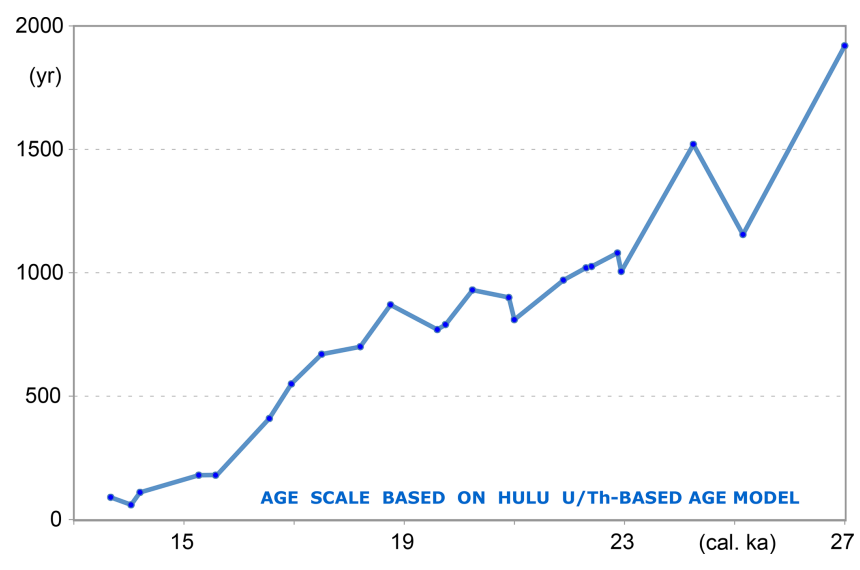

Figure 3. Difference between Hulu Cave U/Th-based model ages (Southon et al., 2012; Bronk Ramsey et al., 2012; Cheng et al., 2018) and varve-count-based calibrated ages for atmospheric ${ }^{14} \mathrm{C}$ plateau boundaries in Lake Suigetsu sediment record (Schlolaut et al., 2018) (Sarnthein et al., 2015, supplemented and revised), displayed on the U/Th-based timescale 13-27 cal ka.

technique (Sarnthein et al., 2007, 2015), since each reservoir age presents the simple difference in average ${ }^{14} \mathrm{C}$ age for one and the same ${ }^{14} \mathrm{C}$ plateau likewise defined in both the Suigetsu atmospheric and planktic ${ }^{14} \mathrm{C}$ records of marine surface waters, independent of the precise position of this plateau on the calendar age scale.

In view of the recent revision of timescales (Schlolaut et al., 2018; Bronk Ramsey et al., 2020), we now extended our plateau tuning and also defined the boundaries and age ranges of ${ }^{14} \mathrm{C}$ plateaus and jumps for the interval $\sim 23$ $29 \mathrm{cal} \mathrm{ka}$, which results in a total of $\sim 30$ atmospheric age tie points for the time span 10.5-29 cal ka (Fig. 1; summary in Table 1; following the rules of Sarnthein et al., 2007, 2015). Prior to $25 \mathrm{cal}$ ka, the definition of ${ }^{14} \mathrm{C}$ plateaus somewhat suffered from an enhanced scatter of raw ${ }^{14} \mathrm{C}$ values of Suigetsu. In addition to visual inspection, the ${ }^{14} \mathrm{C}$ jumps and plateaus were also defined with higher statistical objectivity by means of the first derivative of all trends in the ${ }^{14} \mathrm{C}$ ageto-calendar age relationship (or ${ }^{14} \mathrm{C}$ age-to-core relationship, respectively) by using a running kernel window (Sarnthein et al., 2015).

\subsection{Linkages of short-term structures in the atmospheric ${ }^{14} \mathrm{C}$ record to changes in cosmogenic ${ }^{14} \mathrm{C}$ production vs. changes in ocean dynamics}

Potential sources of variability in the atmospheric ${ }^{14} \mathrm{C}$ record were first discussed by Stuiver and coworkers in the context of Holocene fluctuations deduced from tree ring data (e.g., Stuiver and Braziunas, 1993), which have more recently also been simulated (e.g., Hain et al., 2014). Similar to changes in ${ }^{14} \mathrm{C}$, variations in ${ }^{10} \mathrm{Be}$ deposition in ice cores reflect past changes in ${ }^{10} \mathrm{Be}$ production as a result of changes in solar activity and the strength of the Earth's magnetic field (Adolphi et al., 2018). If we omit assumptions on the modulation of past ${ }^{14} \mathrm{C}$ concentrations by changes in the global carbon cycle, we can calculate the atmospheric ${ }^{14} \mathrm{C}$ changes over last glacial-to-deglacial periods with ${ }^{10} \mathrm{Be}$ and a carbon cycle model and convert them into ${ }^{14} \mathrm{C}$ ages (Fig. 4). Changes in climate and carbon cycle over this period, however, necessarily modified the ${ }^{10} \mathrm{Be}$-based ${ }^{14} \mathrm{C}$ record if included correctly into the modeling. Between 10 and $13.5 \mathrm{cal} \mathrm{ka}$, the ${ }^{10} \mathrm{Be}$-modeled ${ }^{14} \mathrm{C}$ record displays a number of plateau structures that appear to match the Suigetsu-based atmospheric ${ }^{14} \mathrm{C}$ plateaus. Between 15 and $29 \mathrm{cal} \mathrm{ka}$, however, ${ }^{10} \mathrm{Be}$-based ${ }^{14} \mathrm{C}$ plateaus are more rare and/or less pronounced than those in the Suigetsu record. Most modeled plateaus are far shorter than those displayed in the suite of atmospheric ${ }^{14} \mathrm{C}$ plateaus of Lake Suigetsu (e.g., plateaus near the top of $2 a, 2 b$, the top of 5a, and 9), except for a distinct equivalent of plateau no. 6a. On the whole, the modeled and observed structures show little coherence. This may indicate that any direct relationship between variations in cosmogenic ${ }^{14} \mathrm{C}$ production and the Suigetsu plateau record is largely obscured by the carbon cycle, uncorrected climate effects on the ${ }^{10} \mathrm{Be}$ deposition, and/or noise in the ${ }^{14} \mathrm{C}$ data. In addition, a relatively high uncertainty in the measured ${ }^{10} \mathrm{Be}$ concentrations in the ice (in many cases $\sim 7 \%$; Raisbeck et al., 2017) and a lower sample resolution on the order of 50 to 200 years may contribute to the smoothed character of the ${ }^{10} \mathrm{Be}$ record in Fig. 4.

On the other hand, the "new" U/Th-based calibrated ages of plateau boundaries may suggest some reasonable stratigraphic correlations between peak glacial and deglacial change in atmospheric $\mathrm{CO}_{2}$ and ${ }^{14} \mathrm{C}$ plateaus with millennial-scale events in paleoceanography (Fig. 6, Table 2): the suite of deglacial ${ }^{14} \mathrm{C}$ plateaus no. $2 \mathrm{a}, 1$, and Top YD indeed displays a temporal match with three brief but major deglacial jumps in ocean degassing of $\mathrm{CO}_{2}$ documented in the West Antarctic Ice Sheet Divide (WDC) ice core (Marcott et al., 2014). The two records have been independently dated by means of annual-layer counts in ice cores and $\mathrm{U} / \mathrm{Th}$ ages of stalagmites. The match suggests that these atmospheric ${ }^{14} \mathrm{C}$ plateaus may largely result from changes in air-sea gas exchange and, in turn, from changes in ocean dynamics.

In particular, these events may have been linked to a variety of fast changes, such as in sea ice cover in the Southern Ocean and/or in the salinity and buoyancy of high-latitude surface waters (Skinner et al., 2010; Burke and Robinson, 2012). These factors control upwelling and meridional overturning of deep waters, in particular found in the Southern Ocean (Chen et al., 2015) and/or North Pacific (Rae et al., 2014; Gebhardt et al., 2008). Such events of changes in MOC geometry and intensity may be responsible for ocean degassing and the ${ }^{14} \mathrm{C}$ plateaus. The enhanced mixing of the Southern Ocean and a similar, slightly later mixing event in the North Pacific (MD02-2489; Fig. S2d) may have triggered - with phase lag - two trends in parallel: (1) a rise in at- 
Table 2. Temporal match of various ${ }^{14} \mathrm{C}$ plateaus with deglacial periods of major atmospheric $\mathrm{CO}_{2}$ rise and ocean warmings $(\mathrm{AA}$ stands for Antarctic, and GIS stands for Greenland Interstadial).

\begin{tabular}{|c|c|c|c|}
\hline \multicolumn{4}{|c|}{ Deglacial events of $p \mathrm{CO}_{2}$ rise vs. age of planktic ${ }^{14} \mathrm{C}$ plateaus (in cal ka) } \\
\hline$p \mathrm{CO}_{2}$ rise $(\sim 12 \mathrm{ppm})$ & & Plateau no. & Plateau boundaries \\
\hline $\begin{array}{l}\text { AGE based on annual } \\
\text { layers in AA ice core } \\
\text { (Marcott et al. 2014) }\end{array}$ & & & $\begin{array}{l}\text { Age range (cal ka) based on } \\
\text { U/Th model ages } \\
\text { (Bronk Ramsey et al., 2012) }\end{array}$ \\
\hline $11.7-11.5$ & & "Top YD" & $11.83-11.3$ \\
\hline $14.8-14.53$ & & 1 & $15.1-14.2$ \\
\hline $16.4-16.15$ & & $2 \mathrm{a}$ & $16.52-15.5$ \\
\hline $17.4-\sim 17.1$ & & (data gap) & $17.3-17.1$ \\
\hline \multirow[t]{4}{*}{ Further potential correlatives: } & $\begin{array}{l}\text { Progressive N. Atlantic } \\
\text { warming during the YD } \\
\text { at } 12.39-12.03 \mathrm{ka}^{\mathrm{a}}\end{array}$ & "YD” & $12.46-11.98$ \\
\hline & $\begin{array}{l}\text { Onset of Antarctic }{ }^{\mathrm{b}} \\
\text { warming at } 18.3-17.6 \mathrm{ka} \\
\text { (ice-based timescale) }\end{array}$ & 3 & $18.22-17.5$ \\
\hline & $\begin{array}{l}\text { Onset of North Atlantic } \\
\text { warming at } 19.3-18.6 \mathrm{ka} \\
\text { (U/Th-based timescale) }\end{array}$ & 4 & $19.6-18.65$ \\
\hline & $\begin{array}{l}\text { Top H2: GIS } 2 \mathrm{~N} \text {. Atlantic warming } \\
\text { at } 23.4-23.3 \mathrm{ka}^{\mathrm{d}}\end{array}$ & 8 & $24.25-22.95$ \\
\hline
\end{tabular}

Age control based on ${ }^{\mathrm{a}}$ Naughton et al. (2019). Age control based on ${ }^{\mathrm{b}}$ Kawamura et al. (2007). Age control based on ${ }^{\mathrm{c}}$ Balmer and Sarnthein (2018). Age control based on ${ }^{\mathrm{d}}$ Grootes and Stuiver (1997).

mospheric $\mathrm{CO}_{2}$, which was in part abrupt (sensu Chen et al., 2015; Menviel et al., 2018), and (2) a gradual enrichment in ${ }^{14} \mathrm{C}$ depleted atmospheric carbon, reflected as a ${ }^{14} \mathrm{C}$ plateau.

Plateau 6a matches a ${ }^{14} \mathrm{C}$ plateau deduced from atmospheric ${ }^{10} \mathrm{Be}$ concentrations, and thus suggests changes in ${ }^{14} \mathrm{C}$ production. Other changes in atmospheric ${ }^{14} \mathrm{C}$ (plateaus 4 and 8) match short-term North Atlantic warmings during peak glacial and earliest deglacial times, similar to that at the end of HS-1 and during plateau "YD", and hence may reflect minor changes in ocean circulation and oceanatmosphere exchange without major degassing of old ${ }^{14} \mathrm{C}$ depleted deep waters in the North Atlantic (Table 2, Fig. S2a). There is still little information, however, on the origin of several other peak glacial ${ }^{14} \mathrm{C}$ plateaus during $17.5-29 \mathrm{cal} \mathrm{ka}$. The actual linkages of these plateaus to events in ocean MOC still remain to be uncovered.

\section{Discussion and implications}

3.1 ${ }^{14} \mathrm{C}$ plateau boundaries - a suite of narrow-spaced age tie points to rate short-term changes in marine sediment budgets, chemical inventories, and climate during 29-10 cal ka

In continuation of previous efforts (Sarnthein et al., 2007, 2015) the tuning of high-resolution planktic ${ }^{14} \mathrm{C}$ records of ocean sediment cores to the new age-calibrated atmospheric ${ }^{14} \mathrm{C}$ plateau boundaries now makes it possible to establish a "rung ladder" of $\sim 30$ age tie points covering the time span 29-10 cal ka. These global tie points have a time resolution of several hundred to thousands of years and are used to constrain the chronology and potential leads and lags of events that occurred during peak glacial and deglacial times (Fig. 1). The locations of 18 (20; depending on the age range covered) ${ }^{14} \mathrm{C}$ records are shown in Fig. 7 . Figures 8 and $\mathrm{S} 2$ give the time histories of the planktic and benthic reservoir ages; the information they provide is discussed below.

Six prominent examples showing the power and value of additional information obtained by means of the ${ }^{14} \mathrm{C}$ plateautuning method are as follows.

i. The timing of ocean signals of the onset of deglaciation (sudden depletion of planktic $\delta^{18} \mathrm{O}$ and rise in SST) in the North Atlantic and North Pacific can now 

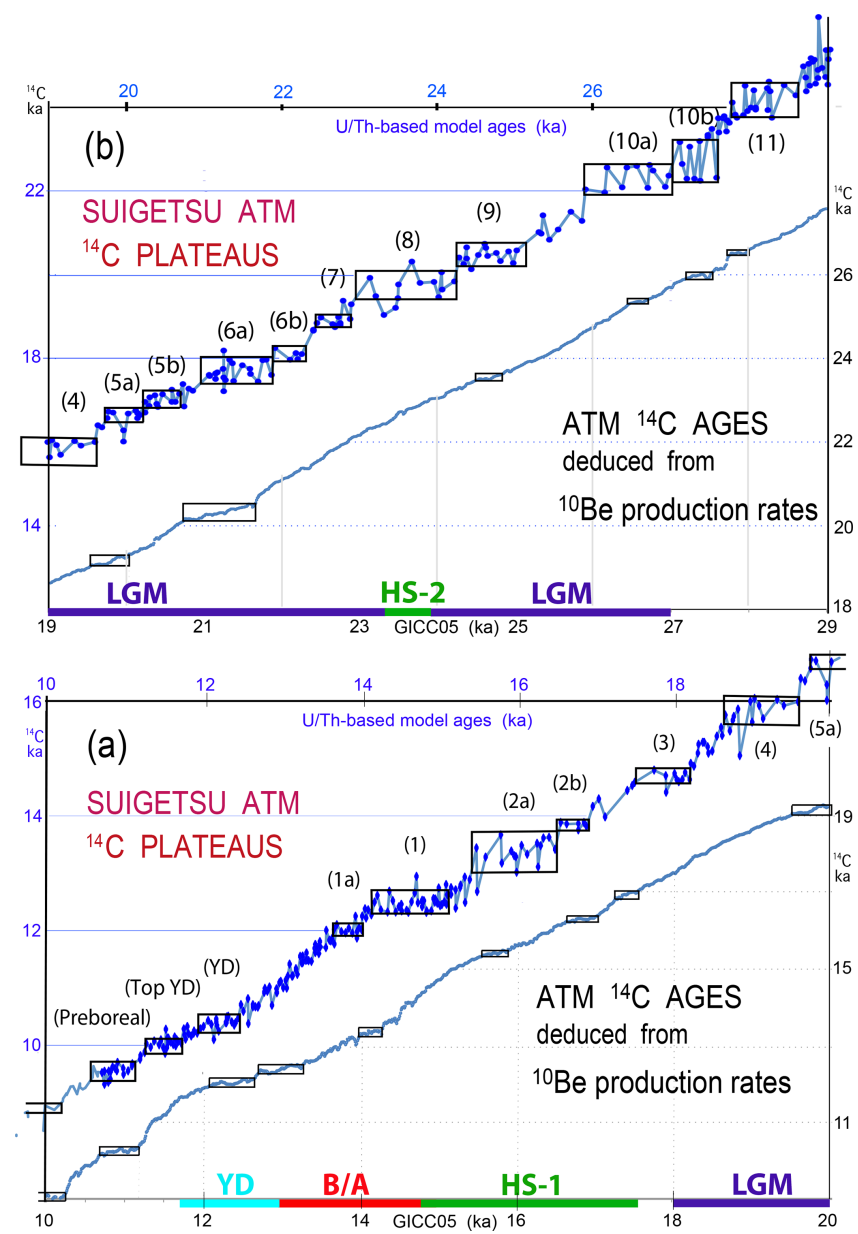

Figure 4. (a, b) Atmospheric ${ }^{14} \mathrm{C}$ ages and plateaus (horizontal boxes) deduced from ${ }^{10} \mathrm{Be}$ production rates vs. GICC05 age scale (Adolphi et al., 2018) compared to the Suigetsu record of atmospheric ${ }^{14} \mathrm{C}$ plateaus vs. Hulu Cave U/Th-based model ages (Southon et al., 2012; Cheng et al., 2018) for the intervals (a) 1020 and (b) 19-29 cal ka BP.

be distinguished in detail from those in the Southern Hemisphere, where warming began at $17.6 \mathrm{cal} \mathrm{ka}$, when the cooling of Heinrich 1 started in the North Atlantic (Fig. S2) (Küssner et al., 2020a, in harmony with Schmittner and Lund, 2015), a finding important to further constrain global "bipolar see-saw" (Stocker and Johnsen, 2003).

ii. Likewise, the end of the cooling equated with the Antarctic Cold Reversal (ACR; WAIS Divide Project Members, 2013) in Pacific surface waters off Central Chile was found to be precisely coeval with the onset of the Younger Dryas cold spell in the Northern Hemisphere (Küssner et al., 2020a).

iii. Signals of local deep-water formation in the subpolar North Pacific can now be separated from signals originating in the North Atlantic (Rae et al., 2014; Sarnthein

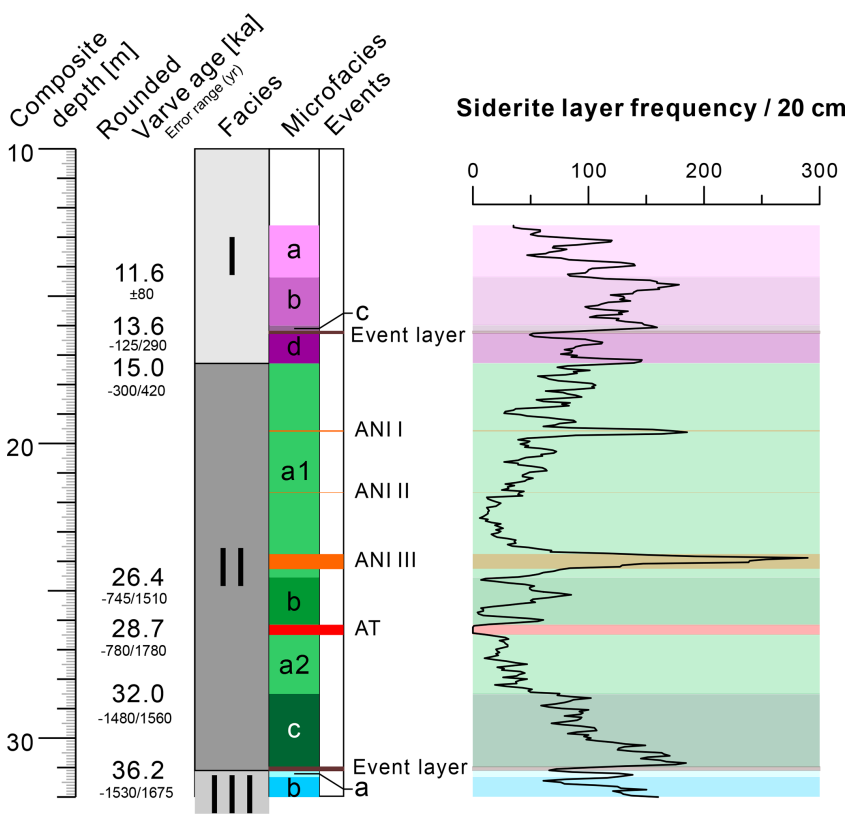

Figure 5. Sediment facies and microfacies zones in Lake Suigetsu Core SG06, 13-32 m depth (simplified and supplemented from Schlolaut et al., 2018). Microscopy-based frequency of siderite layers with quality level 1-3 (i.e., running average of layer counts per $20 \mathrm{~cm}$ thick sediment section) serves as a measure of seasonal lamination quality and shows gradual transitions between varved and poorly varved sediment sections. Rounded varve ages are microscopy based and constrain the age of major facies and microfacies boundaries. ANI I to ANI III mark core sections with ultrafine lamination due to sedimentation rate minima, AT marks the tephra layer named AT, "event layers" label major thin mud slides that are probably earthquake-induced.

et al., 2013). In this way, we can now specify and tie major short-lasting reversals in Atlantic and Pacific MOC on a global scale.

iv. Signals of deglacial meltwater advection can now be distinguished from short-term interstadial warmings in the northern subtropical Atlantic, which helps to locate meltwater outbreaks far beyond the well-known Heinrich belt of ice-rafted debris (Balmer and Sarnthein, 2018).

v. As outlined above, the timing of marine ${ }^{14} \mathrm{C}$ plateaus can now be compared in detail with that of deglacial events of climate and atmospheric $\mathrm{CO}_{2}$ rise that are independently dated by means of ice core-based stratigraphy (Table 2; Fig. 6). These linkages offer a tool to explore details of deglacial changes in deep-ocean MOC once the suite of ${ }^{14} \mathrm{C}$ plateaus has been properly tuned at any particular ocean site.

vi. The refined scale of age tie points also reveals unexpected details for changes in the sea ice cover of high latitudes, as reflected by anomalously high ${ }^{14} \mathrm{C}$ reservoir 


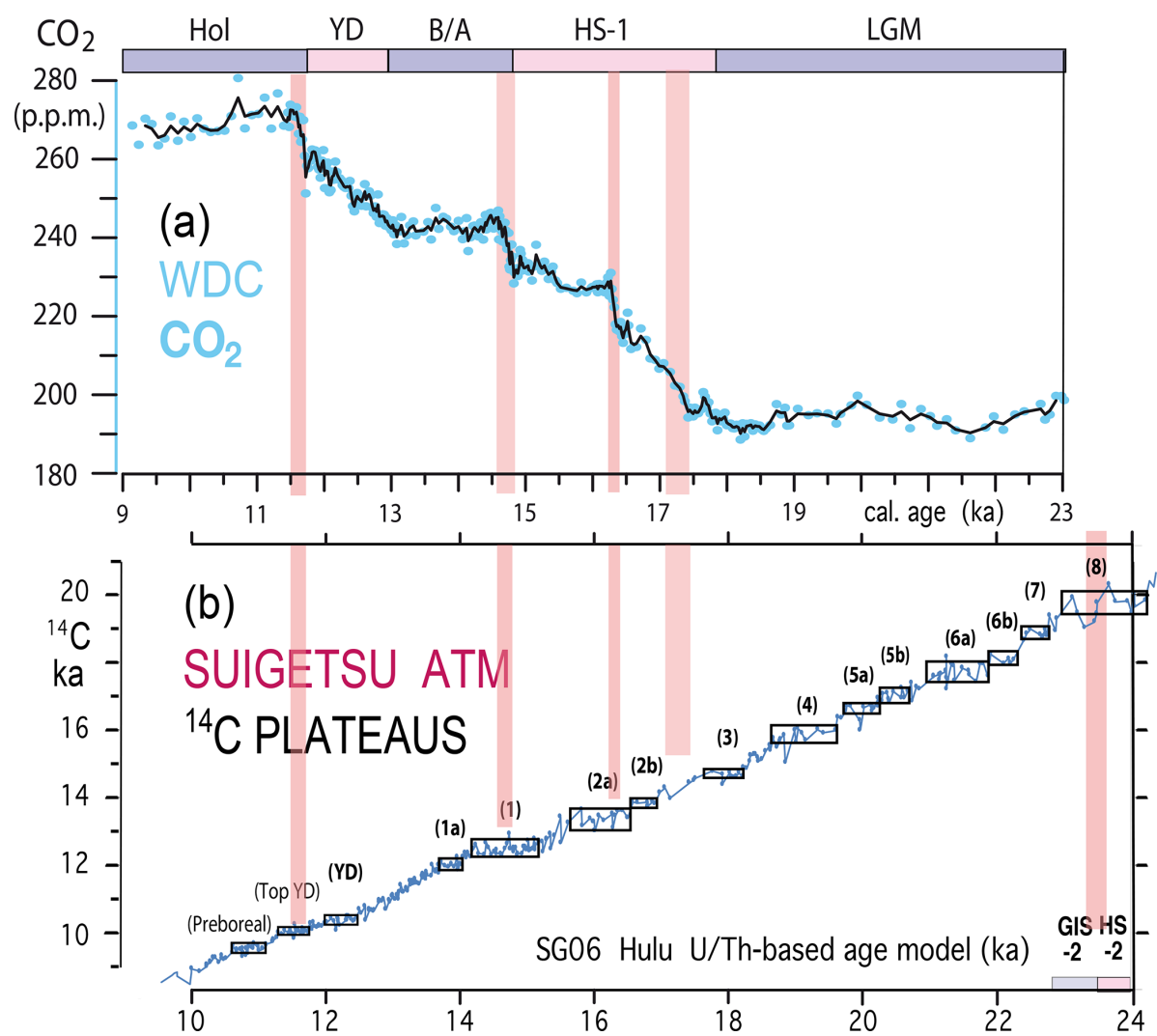

Figure 6. (a) Four sudden steps (pink bars) in the deglacial atmospheric $\mathrm{CO}_{2}$ rise at West Antarctic Ice Sheet Divide ice core (WDC) reflect events of fast ocean degassing, that may have contributed to the origin of deglacial ${ }^{14} \mathrm{C}$ plateaus. Age control based on ice cores (Marcott et al., 2014). (b) The steps are compared to suite of atmospheric ${ }^{14} \mathrm{C}$ plateaus dated by Hulu U/Th-based model ages (Bronk Ramsey et al., 2012). Hol stands for Holocene, YD stands for Younger Dryas, B/A stands for Bølling-Allerød, HS stands for Heinrich stadials 1 and 2 , LGM stands for Last Glacial Maximum, and GIS-2 stands for Greenland interstadial 2.

ages (e.g. north of Iceland and near the Azores Islands), and for the evolution of the Asian summer monsoon in the Northern Hemisphere and Southern Hemisphere, as reflected by periods of reduced sea surface salinity (e.g., Sarnthein et al., 2015; Balmer and Sarnthein, 2018).

Finally, the plateau-based high-resolution chronology has led to the detection of numerous millennial-scale hiatuses (e.g., Sarnthein et al., 2015; Balmer et al., 2016; Küssner et al., 2020a) overlooked by conventional, e.g., AnalySeriebased methods (Paillard et al., 1996), of stratigraphic correlation (Fig. S2). In turn, the hiatuses give intriguing new insights into past changes of bottom current dynamics linked to different millennial-scale geometries of overturning circulation and climate change such as in the South China Sea (Sarnthein et al., 2013, 2015), in the South Atlantic (Balmer et al., 2016), and southern South Pacific (Ronge et al., 2019).

Clearly, the new atmospheric ${ }^{14} \mathrm{C}$ "rung ladder" of closelyspaced chronostratigraphic tie points has evolved into a valuable tool to uncover functional chains in paleoceanography that actually have controlled events of climate change over glacial-to-deglacial times. The extension of the age range back to $29 \mathrm{ka}$ allows for constraining potential changes in the ocean dynamics expected for Dansgaard Oeschger (DO) events 2, 3, and 4 as compared to those found for DO-1, though pertinent core records are still missing.

\subsection{Observed vs. model-based ${ }^{14} \mathrm{C}$ reservoir ages that act as a tracer of past changes in surface ocean dynamics provide incentive for model refinements}

Radiocarbon plateau tuning of marine sediment sections to the Suigetsu ${ }^{14} \mathrm{C}$ atmospheric master record allows us to establish the difference between the average ${ }^{14} \mathrm{C}$ age of coeval atmospheric and planktic ${ }^{14} \mathrm{C}$ plateaus at semi-millennialscale resolution. The suite of changing ${ }^{14} \mathrm{C}$ reservoir ages over time forms a prime tracer of past ocean dynamics influencing local surface waters and a data set crucial to deducing past apparent deep-water ventilation ages (e.g., Muglia et al., 2018; Cook and Keigwin, 2015; Balmer and Sarnthein, 2018).

To better constrain the water depth of past reservoir ages, we dated monospecific planktic foraminifera (Sarnthein et al., 2007): at low latitudes to midlatitudes we used G. bul- 

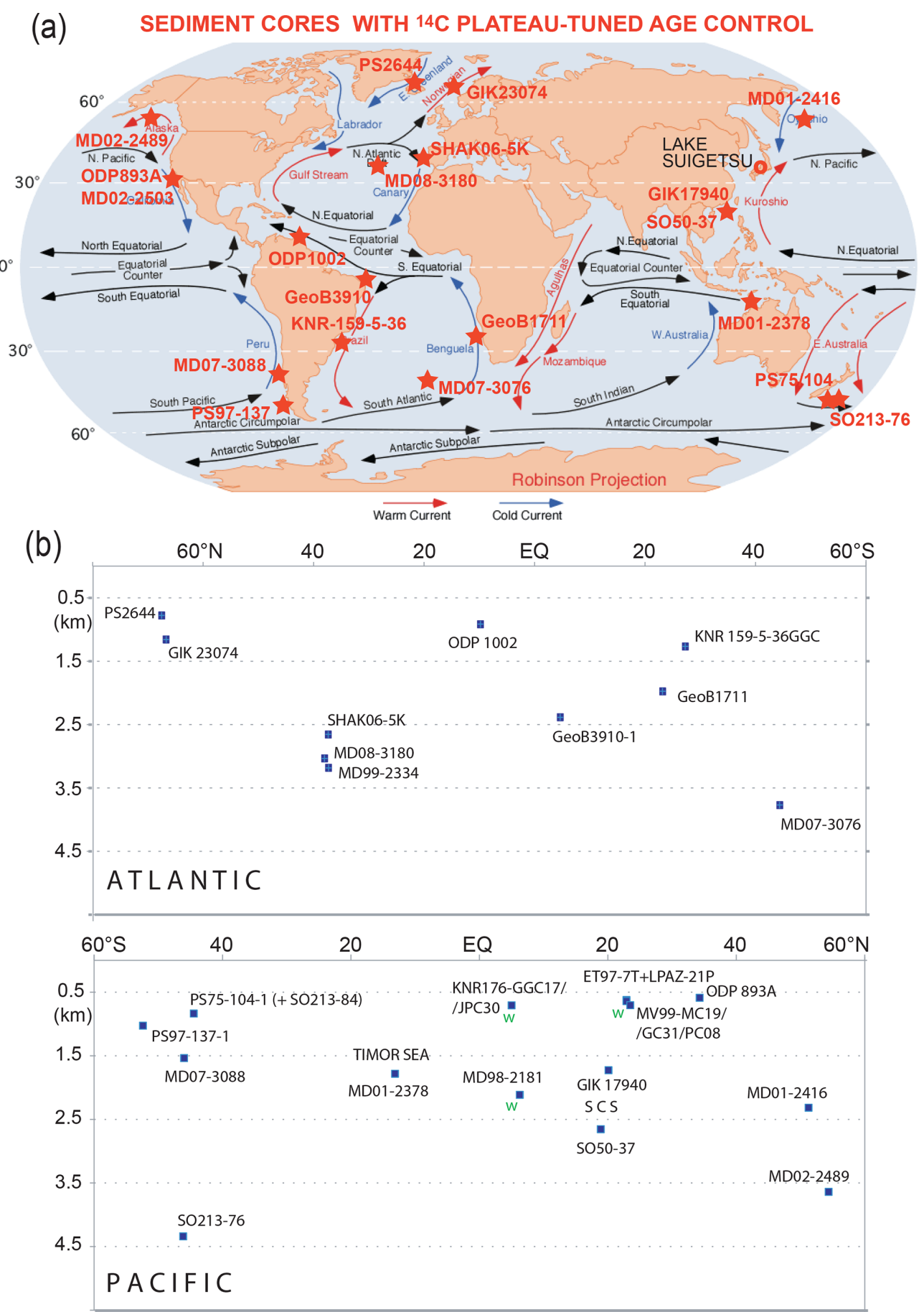

Figure 7. Location (a) and water depth $(\mathrm{km})(\mathbf{b})$ of sediment cores with age control based on ${ }^{14} \mathrm{C}$ plateau tuning. ${ }^{14} \mathrm{C}$ reservoir ages of cores labeled with "w" are derived from samples with paired wood chunks and planktic foraminifers.

loides, G. ruber, or G. sacculifer with habitat depths of 0-80/120 m (Jonkers and Kucera, 2017), and at high latitudes we mostly used $N$. pachyderma (s) living at $0-200 \mathrm{~m}$ depth (Simstich et al., 2003). Averaging of ${ }^{14} \mathrm{C}$ ages within a ${ }^{14} \mathrm{C}$ plateau helps to remove analytical noise and minor real ${ }^{14} \mathrm{C}$ fluctuations. Nine plateaus are located in the LGM, 18
27 cal ka (Fig. 1). Here, planktic foraminifera-based reservoir ages show analytical uncertainties of $>200$ to $>300$ years each for standard Accelerator Mass Spectrometry (AMS) dating. By comparison, short-term temporal variations in reservoir age reach 200-400 years, and occasionally up to 
(a)

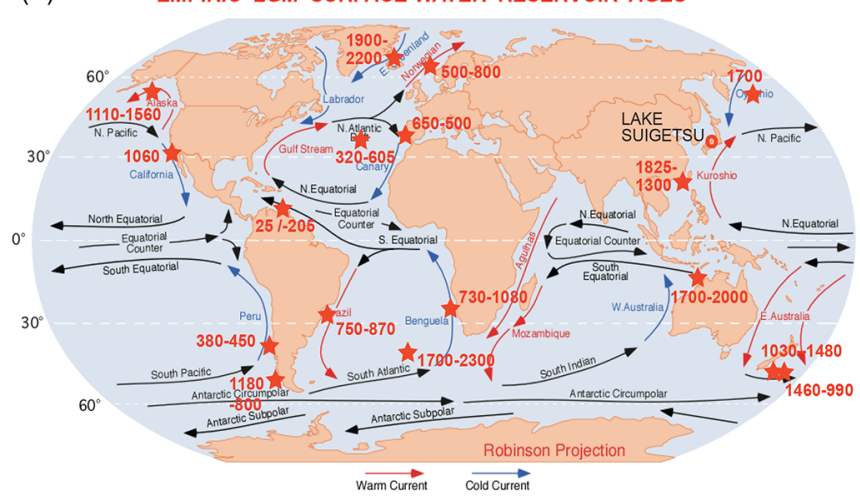

(b)

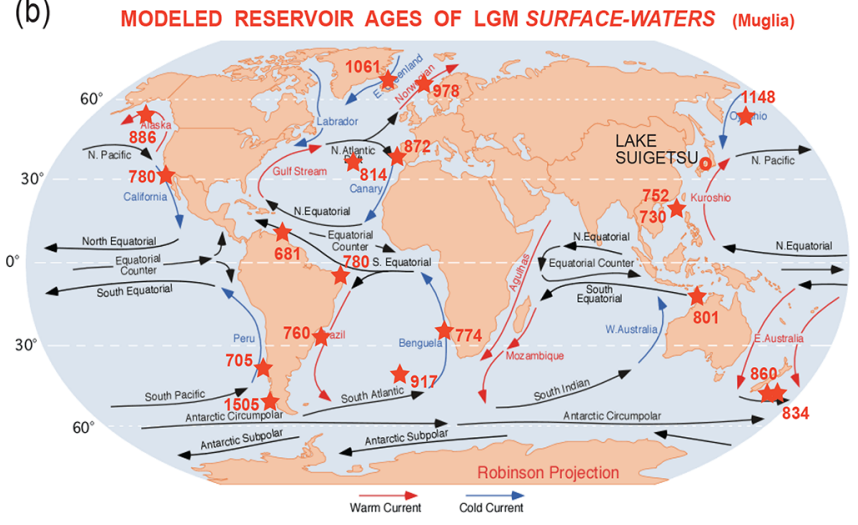

(c) EMPIRIC minus Muglia MODEL RESERVOIR AGES (yr) of LGM S.W.

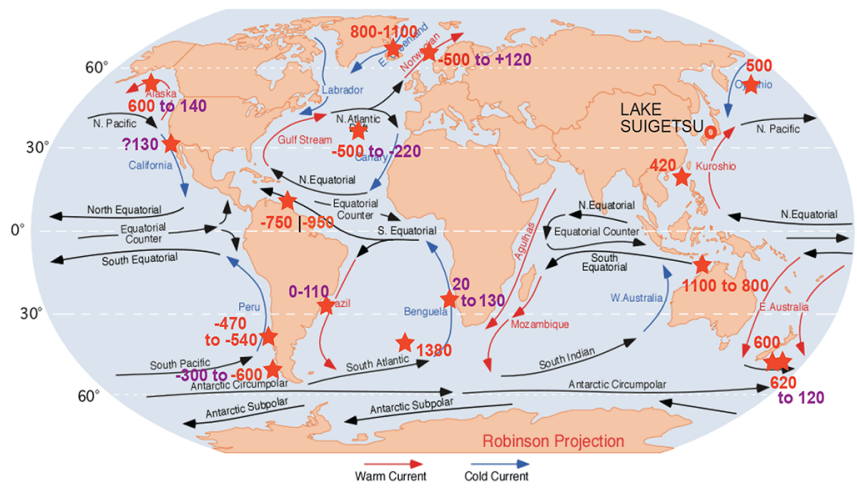

(d) MODEL

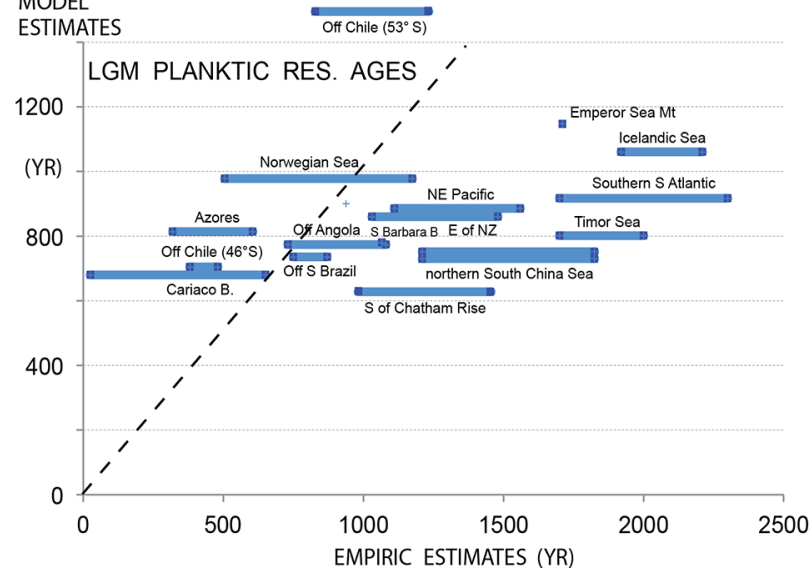

Figure 8. Global distribution of ${ }^{14} \mathrm{C}$ reservoir ages of Late LGM surface waters estimated (a) by means of ${ }^{14} \mathrm{C}$ plateau tuning of planktic ${ }^{14} \mathrm{C}$ records. (b) Model-based estimates (GCM of Muglia et al., 2018, assuming an Atlantic Meridional Overturning Circulation, AMOC, strength of $13 \mathrm{~Sv}$ ) for sites with planktic foraminifera-based age values. The $x-y$ graph (d) and map (c) show (rounded) differences between observed and modeled values and their intra-LGM trends. Minor differences are displayed in magenta, and larger differences of $>400$ years are shown in red. Planktic habitat depths and model estimates are largely confined to $0-100 \mathrm{~m}$ water depth. Arrows of surface currents delineate different sea regions important to assess potential limits of spatial extrapolation of reservoir ages. Distribution of core numbers and references for ${ }^{14} \mathrm{C}$ records are given in Table 3 and Fig. $7 \mathrm{a}$.

600 years, particularly when close to the end of the LGM (Table 3).

To better decode the informative value of our ${ }^{14} \mathrm{C}$ reservoir ages for late LGM we compared average ages of ${ }^{14} \mathrm{C}$ Plateaus 4-5 (18.6-20.9 cal ka) with estimates generated by various global ocean models, an approach similar to that of Toggweiler et al. (2019) applied to modern reservoir ages of the global ocean. In an earlier paper (Balmer et al., 2016), we compared our empiric reservoir ages for the LGM with GCM-based estimates of Franke et al. (2008) and Butzin et al. (2012). Franke et al. (2008) underestimated our midlatitude values by up to $\sim 2000{ }^{14} \mathrm{C}$ years, while LGM reservoir age estimates of Butzin et al. (2012) were more consistent with ours. Their GCM considered more realistic boundary conditions, such as the LGM freshwater balance in the Southern Ocean and, in particular, LGM SST and wind fields plus the gas transfer velocity for the exchange of ${ }^{14} \mathrm{C}$ of $\mathrm{CO}_{2}$ (Sweeney et al., 2007). Further improvements are ex- pected from a model configuration that properly resolves the topographic details of the continental margins and adjacent seas, which frequently form the origin of our sediment-based data sets (Butzin et al., 2020). For the time being, we compared our empirical estimates with estimates from a coarseresolution GCM, using the results by Muglia et al. (2018; 0 $50 \mathrm{~m}$ water depth (w.d.); Fig. 8c, d; Table 3) as an example. Their model includes ocean surface reservoir age and ocean radiocarbon fields that have been validated through a comparison to LGM ${ }^{14} \mathrm{C}$ data compilation made by Skinner et al. (2017). It conforms two plausible, recent model estimates of surface reservoir ages that can be compared to our results (Table 3).

Low LGM values (300-750 years) supposedly document an intensive exchange of surface waters with atmospheric $\mathrm{CO}_{2}$, most common in model- and foraminifera-based estimates of the low-latitude and midlatitude Atlantic. Low empiric values also mark LGM waters in midlatitudes to 
Table 3. (a-c) The ${ }^{14} \mathrm{C}$ reservoir and ventilation ages of surface (top 50-100 $\mathrm{m}$ ) and bottom waters vs. U/Th-based model age at 19 and 22 core sites in the ocean, respectively. (a) Spatial and temporal changes over the early and late LGM (24-21 and 21-18.7 cal ka), (b) HS-1, and the B/A. Late LGM estimates (average reservoir age of Plateau 4-5) are compared to model-based estimates of Muglia et al. (2018). (c) Data sources. For core locations see Fig. 7.

\begin{tabular}{|c|c|c|c|c|c|c|c|c|c|}
\hline \multicolumn{10}{|l|}{ (a) } \\
\hline \multirow{2}{*}{$\begin{array}{l}\text { Sediment core } \\
\text { U/Th-based model ag }\end{array}$} & \multirow{3}{*}{$\begin{array}{l}\text { Latitude } \\
\text { e }\end{array}$} & \multirow[t]{3}{*}{ Longitude } & \multirow{3}{*}{$\begin{array}{r}\text { Water depth } \\
\text { (m) }\end{array}$} & \multicolumn{4}{|c|}{ LGM pla. res. age } & \multicolumn{2}{|c|}{ LGM model res. age } \\
\hline & & & & \multicolumn{2}{|c|}{$\begin{array}{c}\text { 24-21 ka } \\
\text { (early LGM) }\end{array}$} & \multicolumn{2}{|c|}{$\begin{array}{r}21-18.7 \mathrm{ka} \\
\text { (late LGM) }\end{array}$} & \multirow{2}{*}{$\begin{array}{r}\text { strong } \\
\text { AMOC } \\
\text { (year) }\end{array}$} & \multirow{2}{*}{$\begin{array}{r}\text { weak } \\
\text { AMOC } \\
\text { (year) }\end{array}$} \\
\hline${ }^{14} \mathrm{C}$ Plateau (Pl.) no. & & & & Pl. 8-7-6 & Error (year) & Pl. 5-4 & Error (year) & & \\
\hline \multicolumn{10}{|l|}{ Atlantic Ocean } \\
\hline PS2644 & $67^{\circ} 52.02^{\prime} \mathrm{N}$ & $21^{\circ} 45.92^{\prime} \mathrm{W}$ & 777 & 2100 & \pm 390 & $1920-2200$ & \pm 325 to \pm 125 & 1136 & 1100 \\
\hline GIK 23074 & $66^{\circ} 66.67^{\prime} \mathrm{N}$ & $4^{\circ} 90^{\prime} \mathrm{E}$ & 1157 & $620-790$ & \pm 145 to \pm 270 & $550-1175$ & \pm 100 to \pm 200 & 1054 & 1059 \\
\hline MD08-3180 & $38^{\circ} \mathrm{N}$ & $31^{\circ} 13.45^{\prime} \mathrm{W}$ & 3064 & - & & $320-605$ & \pm 125 to \pm 405 & 827 & 887 \\
\hline SHAK06-5K & $37^{\circ} 34^{\prime} \mathrm{N}$ & $10^{\circ} 09^{\prime} \mathrm{W}$ & 2646 & $675-800$ & & $500-660$ & & 872 & 855 \\
\hline (= MD99-2334) & $37^{\circ} 48^{\prime} \mathrm{N}$ & $10^{\circ} 10^{\prime} \mathrm{W}$ & 3146 & & & & & & \\
\hline ODP 1002 & $10^{\circ} 42.37^{\prime} \mathrm{N}$ & $65^{\circ} 10.18^{\prime} \mathrm{W}$ & 893 & $700-210$ & \pm 230 to \pm 310 & 25 to -205 & \pm 205 to \pm 215 & 751 & 738 \\
\hline GeoB 3910-1 & $4^{\circ} 15^{\prime} \mathrm{S}$ & $36^{\circ} 21^{\prime} \mathrm{W}$ & 2361 & - & & - & & 779 & 796 \\
\hline GeoB 1711-4 & $23^{\circ} 17^{\prime} \mathrm{S}$ & $12^{\circ} 23^{\prime} \mathrm{W}$ & 1976 & 1080 & \pm 290 & $730-840$ & \pm 240 to \pm 190 & 711 & 721 \\
\hline KNR 159-5-36GGC & $27^{\circ} 31^{\prime} \mathrm{S}$ & $46^{\circ} 48^{\prime} \mathrm{W}$ & 1268 & 540 & \pm 140 & 870 & \pm 120 & 757 & 777 \\
\hline MD07-3076 & $44^{\circ} 4^{\prime} \mathrm{S}$ & $4^{\circ} 12^{\prime} \mathrm{W}$ & 3770 & - & & 2300 & \pm 200 & 928 & 989 \\
\hline \multicolumn{10}{|c|}{ Indian Ocean/Timor Sea } \\
\hline MD01-2378 & $13^{\circ} 08.25^{\prime} \mathrm{S}$ & $121^{\circ} 78.8^{\prime} \mathrm{E}$ & 1783 & - & & $2000-1700$ & \pm 300 to \pm 320 & 885 & 890 \\
\hline \multicolumn{10}{|l|}{ Pacific Ocean } \\
\hline MD02-2489 & $54^{\circ} 39.07^{\prime} \mathrm{N}$ & $148^{\circ} 92.13^{\prime} \mathrm{W}$ & 3640 & - & & $1560-1110$ & \pm 310 to \pm 335 & 972 & 965 \\
\hline MD01-2416 & $51^{\circ} 26.8^{\prime} \mathrm{N}$ & $167^{\circ} 72.5^{\prime} \mathrm{E}$ & 2317 & - & & 1710 & \pm 440 & 1227 & 1202 \\
\hline ODP 893A & $34^{\circ} 17.25^{\prime} \mathrm{N}$ & $120^{\circ} 02.33^{\prime} \mathrm{W}$ & 588 & - & & 1065 & \pm 280 & 839 & 846 \\
\hline MD02-2503 & $34^{\circ} 16.6^{\prime} \mathrm{N}$ & $120^{\circ} 01.6^{\prime} \mathrm{W}$ & 580 & - & & - & & 839 & 846 \\
\hline GIK 17940 & $20^{\circ} 07.0^{\prime} \mathrm{N}$ & $117^{\circ} 23.0^{\prime} \mathrm{E}$ & 1727 & $1820-1260$ & \pm 320 to \pm 230 & hiatus & & 836 & 838 \\
\hline$(=\mathrm{SO} 50-37)$ & $18^{\circ} 55^{\prime} \mathrm{N}$ & $115^{\circ} 55^{\prime} \mathrm{E}$ & 2655 & $1820-1260$ & & & & 836 & 840 \\
\hline PS75/104-1 & $44^{\circ} 46^{\prime} \mathrm{S}$ & $174^{\circ} 31^{\prime} \mathrm{E}$ & 835 & $1650-1280$ & \pm 210 to \pm 320 & 1500 & \pm 340 & 881 & 895 \\
\hline$(=\mathrm{SO} 213-84)$ & $45^{\circ} 7.5^{\prime} \mathrm{S}$ & $174^{\circ} 34.9^{\prime} \mathrm{E}$ & 972 & $1650-1280$ & \pm 210 to \pm 3201500 & \pm 340 & 881 & 895 & \\
\hline MD07-3088 & $46^{\circ} \mathrm{S}$ & $75^{\circ} \mathrm{W}$ & 1536 & 385 & \pm 315 & $380-450$ & \pm 140 to \pm 230 & 917 & - \\
\hline SO213-76-2 & $46^{\circ} 13^{\prime} \mathrm{S}$ & $178^{\circ} 1.7^{\prime} \mathrm{W}$ & 4339 & - & & $1460-990$ & \pm 340 to \pm 550 & 915 & 842 \\
\hline PS97/137-1 & $52^{\circ} 39.5^{\prime} \mathrm{S}$ & $75^{\circ} 33.9^{\prime} \mathrm{E}$ & 1027 & $600-1180$ & \pm 465 & $1180-800$ & \pm 90 to \pm 225 & 1505 & 1419 \\
\hline
\end{tabular}

high latitudes off Norway and off central Chile, i.e., close to sites of potential deep and/or intermediate water formation. Off Norway and in the northeastern Atlantic, modelbased reservoir ages of Muglia et al. (2018) largely match the empiric range. However, the uncertainty envelopes for data shown in Fig. $8 \mathrm{c}( \pm 560$ years; $r=0.59)$ generally by far exceed the spatial differences calculated for the empiric data. Conversely, model-based reservoir ages only poorly reproduce the low planktic foraminifera-based estimates off central Chile and values in the western Pacific and Southern Ocean.

In part, the differences may be linked to problems like insufficient spatial resolution along continental margins, ignoring east-west differences within ocean basins, and/or the estimates of a correct location and extent of seasonal sea ice cover used as LGM boundary condition, such as east of Greenland, in the subpolar northwest Pacific, and off southern Chile, where sea ice hindered the exchange of atmospheric carbon (per analogy to that of temperature exchange, e.g., Sessford et al, 2019).In addition, model estimates of the annual average are compared to ${ }^{14} \mathrm{C}$ signals of planktic foraminifera that mostly formed during summer only, e.g., when large parts of the Nordic Seas were found to be icefree (Sarnthein et al., 2003). Hence, models may need to better constrain local and seasonal sealing effects of LGM sea ice cover.

In general, the foraminifera-based reservoir age estimates for our sites that represent various hydrographic key regions in the high-latitude ocean appear to be much higher than model-derived values. These deviations reach up to 1400 years, particularly in the Southern Ocean. In part, they may result from the fact that present models may not yet be suited to capturing small-scale ocean structures such as the interference of ocean currents with local bathymetry and local upwelling cells. Here, model-based reservoir ages appear far too low in LGM regions influenced (i) by regional upwelling such as the South China Sea and thus governed by an estuarine overturning system (Wang et al., 2005; Fig. 9), (ii) by coastal upwelling off northwestern Australia (Xu et al., 2010; Sarnthein et al., 2011), or (iii) when stratified by a meltwater lid, such as off eastern New Zealand (Bostock et al., 2013; Küssner et al., 2020a). Local oceanic features are 
Table 3. Continued.

\begin{tabular}{|c|c|c|c|c|c|c|c|c|c|c|}
\hline \multicolumn{11}{|l|}{ (b) } \\
\hline \multirow{3}{*}{$\begin{array}{l}\text { Sediment core } \\
\mathrm{U} / \text { Th-based } \\
\text { model age } \\
{ }^{14} \mathrm{C} \text { Plateau (Pl.) no. }\end{array}$} & \multicolumn{4}{|c|}{ HS-1 pla. res. age } & \multirow{2}{*}{\multicolumn{2}{|c|}{$\frac{\text { B/A pla. res. age }}{14.7-13.6 \mathrm{ka}}$}} & \multirow{2}{*}{\multicolumn{2}{|c|}{$\begin{array}{c}\text { LGM be. vent age } \\
\text { (year) }\end{array}$}} & \multicolumn{2}{|c|}{ LGM b.w. model age } \\
\hline & \multicolumn{2}{|c|}{$18-16.5 \mathrm{ka}$} & \multicolumn{2}{|c|}{$16.5-15.5 \mathrm{ka}$} & & & & & \multirow{2}{*}{$\begin{array}{r}\text { strong } \\
\text { AMOC } \\
\text { (year) }\end{array}$} & \multirow{2}{*}{$\begin{array}{r}\text { weak } \\
\text { AMOC } \\
\text { (year) }\end{array}$} \\
\hline & $\begin{array}{r}\text { Pl. 3-2b } \\
\text { (year) }\end{array}$ & $\begin{array}{l}\text { Error } \\
\text { (year) }\end{array}$ & $\begin{array}{l}\text { Pl. 2a } \\
\text { (year) }\end{array}$ & $\begin{array}{l}\text { Error } \\
\text { (year) }\end{array}$ & Pl. 1-1a & $\begin{array}{r}\text { Error } \\
\text { (year) }\end{array}$ & early & late & & \\
\hline \multicolumn{11}{|l|}{ Atlantic Ocean } \\
\hline PS2644 & $1775-1660$ & \pm 105 to \pm 160 & 1900 & \pm 355 & - & & 345 & 2400 & 948 & 918 \\
\hline GIK 23074 & $1730-2000$ & \pm 125 to \pm 160 & 670 & \pm 310 & $140-310$ & \pm 250 to \pm 100 & 375 & 375 & 960 & 931 \\
\hline MD08-3180 & $1420-1610$ & \pm 310 to \pm 160 & 1460 & \pm 390 & $630-360$ & \pm 310 & 600 & 600 & 1031 & 1004 \\
\hline SHAK06-5K & $330-410$ & & 535 & & $780-925$ & & - & & - & - \\
\hline (= MD99-2334) & & & & & & & $2200-2700$ & 1900 & - & - \\
\hline ODP 1002 & -100 to 20 & \pm 140 & 90 & \pm 345 & 355 & \pm 200 & - & & 1247 & 1175 \\
\hline GeoB 3910-1 & $630-560$ & \pm 160 to \pm 180 & 175 & \pm 475 & $210-230$ & \pm 220 to \pm 110 & 2150 & 2150 & - & - \\
\hline GeoB 1711-4 & $660-690$ & \pm 195 to \pm 45 & 420 & \pm 320 & 880 & \pm 255 & 1500 & 1500 & 1387 & 1714 \\
\hline KNR 159-5-36GGC & $460-340$ & \pm 380 to \pm 300 & 170 & \pm 700 & $180-230$ & \pm 370 to \pm 310 & 1470 & 1470 & 1354 & 1563 \\
\hline MD07-3076 & 1650 & \pm 180 & - & & 920 & \pm 230 & 3640 & 3640 & 1653 & 2060 \\
\hline \multicolumn{11}{|c|}{ Indian Ocean/Timor Sea } \\
\hline MD01-2378 & 740 & \pm 125 & - & & $200-185$ & \pm 345 to \pm 135 & 2720 & - & 1679 & 1881 \\
\hline \multicolumn{11}{|l|}{ Pacific Ocean } \\
\hline MD02-2489 & $800-550$ & \pm 155 to \pm 120 & 550 & \pm 305 & 440 & \pm 285 & & 2625 & 2332 & 2595 \\
\hline MD01-2416 & $1480-1140$ & \pm 135 to \pm 195 & - & & $720-570$ & \pm 285 to \pm 140 & & $3700 / 5100$ & 2400 & 2683 \\
\hline ODP 893A & $1065-1490$ & \pm 280 to \pm 125 & 1400 & \pm 370 & 520 & \pm 185 & & 1430 & 1677 & 1705 \\
\hline MD02-2503 & $965-1365$ & \pm 160 to \pm 165 & 1215 & \pm 325 & $395-535$ & \pm 240 to \pm 130 & - & - & - & - \\
\hline GIK 17940 & $1210-1370$ & \pm 200 to \pm 470 & 1045 & \pm 320 & $870-970$ & \pm 325 to \pm 100 & $3300-1800$ & & 1807 & 1897 \\
\hline$(=\mathrm{SO} 50-37)$ & & & & & & & 3225 & 3225 & 2373 & 2667 \\
\hline PS75/104-1 & 1050 & \pm 265 & 1180 & \pm 350 & 800 & \pm 280 & - & - & - & - \\
\hline$(=\mathrm{SO} 213-84)$ & & & & & & & 1500 & 2400 & 1101 & 1146 \\
\hline MD07-3088 & $800-1090$ & \pm 85 to \pm 125 & 1060 & \pm 275 & $1310-730$ & \pm 125 to \pm 190 & $1360 ?$ & 1600 & 1808 & 1701 \\
\hline SO213-76-2 & 840 & \pm 310 & - & & - & & & 3460 & 1712 & 2001 \\
\hline PS97/137-1 & $1500-670$ & \pm 90 to \pm 180 & 455 & \pm 270 & - & & $1400-2400$ & $2400 / 2900$ & 1631 & 1871 \\
\hline
\end{tabular}

likely to be missed in current resolution models. Our more narrow-spaced empiric data could help to refine the skill of models to capture past ${ }^{14} \mathrm{C}$ reservoir ages.

Various differences amongst plankton- and model-based reservoir ages may also result from differential seasonal habitats of the different planktic species analyzed that, in turn, may trace different surface and subsurface water currents. Distinct interspecies differences were found in Baja California that record differential, upwelling-controlled habitat conditions (Lindsay et al., 2015). In the northern Norwegian Sea interspecies differences amount up to 600 years for the Preboreal ${ }^{14} \mathrm{C}$ plateau: 9.6-10.2 cal ka (Sarnthein and Werner, 2018). Here ${ }^{14} \mathrm{C}$ records of Arctic Turborotalita quinqueloba, dominantly grown close to the sea surface during peak summer, differ from the paired record of Neogloboquadrina pachyderma, formed in subsurface waters, and that of subpolar species $N$. incompta, mainly advected from the south by Norwegian Current waters that are well mixed with the atmosphere during peak winter. This makes closer specification of model results as a product of different seasonal extremes a further target.
3.3 Planktic foraminifera-based ${ }^{14} \mathrm{C}$ reservoir ages - a prime database to estimate past changes in the ${ }^{14} \mathrm{C}$ ventilation age of deep waters and past oceanic MOC and DIC

"Raw" apparent benthic ventilation ages (in ${ }^{14} \mathrm{C}$ years; "raw" sensu Balmer and Sarnthein, 2018) express the difference between the (coeval) atmospheric and benthic ${ }^{14} \mathrm{C}$ levels measured at any site and time of foraminifer deposition. These ages are the sum of (1) the planktic reservoir age of the ${ }^{14} \mathrm{C}$ plateau that covers a group of paired benthic and planktic ${ }^{14} \mathrm{C}$ ages and (2) the (positive or negative) ${ }^{14} \mathrm{C}$ age difference between any benthic ${ }^{14} \mathrm{C}$ age and the average ${ }^{14} \mathrm{C}$ age of the paired planktic ${ }^{14} \mathrm{C}$ plateau. The benthic ventilation ages necessarily rely on the high quality of ${ }^{14} \mathrm{C}$ plateau-based chronology, since the atmospheric ${ }^{14} \mathrm{C}$ level has been subject to substantial short-term changes over glacial-to-deglacial times. Necessarily, the ventilation ages include a mixing of different water masses that might originate from different ocean regions and may contribute differential ${ }^{14} \mathrm{C}$ ventilation ages, an unknown justifying the modifier "apparent".

In a further step, the $\Delta \Delta^{14} \mathrm{C}$ equivalent of our raw benthic ventilation age may be adjusted to changes in atmo- 
Table 3. Continued.

\begin{tabular}{lll}
\hline (c) & & \\
\hline Sediment core & & Data source \\
\hline Atlantic Ocean & PS2644 & Sarnthein et al. (2015), Benthic data supplemented \\
& GIK 23074 & Sarnthein et al. (2015), Benthic data supplemented \\
& MD08-3180 & Balmer and Sarnthein (2018) \\
& SHAK06-5K & Ausin et al. (2020a) \\
& (= MD99-2334) & Skinner et al. (2014) \\
& ODP 1002 & Sarnthein et al. (2015) \\
GeoB 3910-1 & Balmer et al. (2016) \\
& GeoB 1711-4 & Balmer et al. (2016) \\
& KNR 159-5-36GGC & Balmer et al. (2016), data supplemented \\
& MD07-3076 & Balmer et al. (2016) \\
\hline Indian Ocean/Timor Sea & MD01-2378 & Sarnthein et al. (2015) \\
\hline Pacific Ocean & MD02-2489 & Sarnthein et al. (2015) \\
& MD01-2416 & Sarnthein et al. (2015), modified \\
& ODP 893A & Sarnthein et al. (2015), data supplemented \\
& MD02-2503 & Sarnthein et al. (2015) \\
& GIK 17940 & Sarnthein et al. (2015) \\
(= SO50-37) & Sarnthein et al. (2015) \\
& PS75/104-1 & Küssner et al. (2018, 2020a) \\
(= SO213-84) & Ronge et al. (2016) \\
MD07-3088 & Küssner et al. (2020a), Siani et al. (2013) \\
SO213-76-2 & Küssner et al. (2020a), Ronge et al. (2016) \\
PS97/137-1 & Küssner et al. (2020a), data supplemented \\
\hline
\end{tabular}

spheric ${ }^{14} \mathrm{C}$ that occurred over the (short) time span between deep-water formation and benthic sediment deposition (e.g., Balmer and Sarnthein, 2018; Cook and Keigwin, 2015). In most cases, however, this second step is omitted since its application usually does not imply any major modification of the ventilation age estimates (Fig. S2a; Skinner et al., 2017; Sarnthein et al., 2013).

On the basis of ${ }^{14} \mathrm{C}$ plateau tuning we now can rely on 18 accurately dated records of apparent benthic ${ }^{14} \mathrm{C}$ ventilation ages (Fig. S2a-d) to reconstruct the global geometry of LGM and HS-1 deep and intermediate water circulation, as summarized in ocean transects and maps (Figs. 9-11) and discussed below. The individual matching of our 20 planktic ${ }^{14} \mathrm{C}$ plateau sequences with that of the Suigetsu atmospheric ${ }^{14} \mathrm{C}$ record is displayed in Sarnthein et al. (2015), Balmer et al. (2016), Küssner et al. (2020a), and Ausin et al. (2020a). In addition, robust estimates of past reservoir ages are obtained for four planktic and benthic ${ }^{14} \mathrm{C}$ records from paired atmospheric ${ }^{14} \mathrm{C}$ ages of wood chunks (Rafter et al., 2018; Zhao and Keigwin, 2018; Broecker et al., 2004).

\subsubsection{Major features of ocean meridional overturning circulation during LGM (Fig. 10)}

Off Norway and near the Azores Islands very low benthic ${ }^{14} \mathrm{C}$ ventilation ages of $<100-750$ years suggest ongoing deep-water formation in the LGM northern North Atlantic reaching down to more than 3000-3500 $\mathrm{m}$ water depth, with a flow strength possibly similar to today (and a coeval deep countercurrent of old waters from the Southern Ocean flowing along the East Atlantic continental margin off Portugal). This pattern clearly corroborates the assembled benthic $\delta^{13} \mathrm{C}$ record showing plenty of elevated $\delta^{13} \mathrm{C}$ values for the northwestern, eastern, and central North Atlantic (Sarnthein et al., 1994; Millo et al., 2006; Keigwin and Swift, 2017). Irrespective of unspecified potential zonal variations in deepwater ventilation age at midlatitudes and different from a number of published models (e.g., Ferrari et al., 2014; Butzin et al., 2017), this "anti-estuarine" pattern has been confirmed by a global tracer transport model of Gebbie (2014), MIROC model simulations (Sherriff-Tadano et al., 2017; Yamamoto et al., 2019), and independently by $\varepsilon_{\mathrm{Nd}}$ records (Howe et al., 2016; Lippold et al., 2016). The latter suggests an overturning of AMOC that is possibly even stronger than today, in particular due to a "thermal threshold" (Abé-Ouchi, 2018) overlooked in other model simulations.

In contrast to the northern North Atlantic, deep waters in the southern North Atlantic and circumpolar (CP) deep waters in the subpolar South Atlantic show an LGM ${ }^{14} \mathrm{C}$ ventilation age of $\sim 3640$ years, finally rising up to 3800 years (Figs. 10, 11, S2b). These waters were upwelled and admixed from below to surface waters near the sub-Antarctic Front 

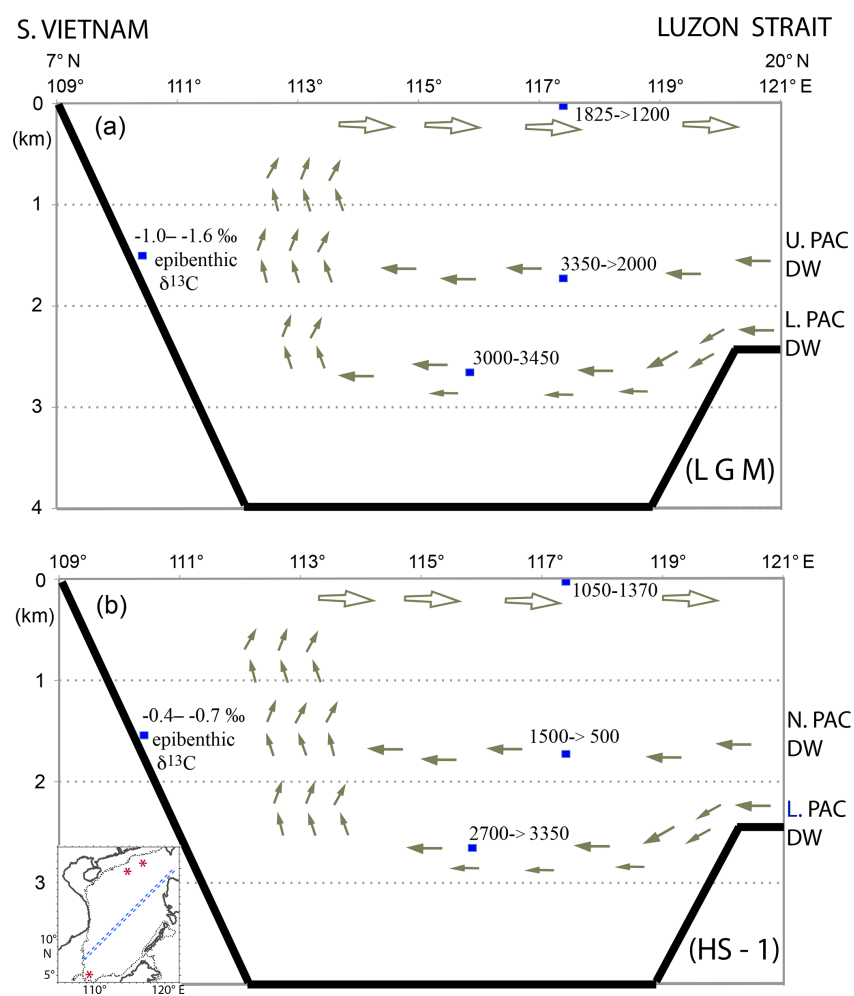

Figure 9. SW-NE transect of ${ }^{14} \mathrm{C}$ reservoir age and changes in ventilation age across sites GIK17940 and SO50-37 in the South China Sea during the late LGM $\left({ }^{14} \mathrm{C}\right.$ Plateaus 5 and 4 ; a) and HS-1 (b). Insert map shows the location of the transect and core locations. Core locations are given in Fig. 7. An extreme epibenthic $\delta^{13} \mathrm{C}$ minimum in the far southwest (Core GIK17964; Wang et al., 1999) reflects an LGM incursion of lower and upper Pacific Deep Waters (L. PAC DW and U. PAC DW) with extremely high ${ }^{14} \mathrm{C}$ ventilation age and DIC enrichment in contrast to a low ventilation age of North Pacific Deep Water (N. PAC DW). Arrows show the direction of potential deep and intermediate water currents.

during the terminal LGM (Fig. S2b; Skinner et al., 2010; Balmer and Sarnthein, 2016; model of Butzin et al., 2012).

In the southwestern South Pacific abyssal, in part possibly Antarctic-sourced waters (Rae and Broecker, 2018) likewise show high apparent ${ }^{14} \mathrm{C}$ ventilation ages of 3500 years that drop to 2750 years near the end of the LGM (Figs. 10 and S2c) $\left({ }^{14} \mathrm{C}\right.$ dates of Ronge et al., 2016, modified by planktic ${ }^{14} \mathrm{C}$ reservoir ages of Küssner et al., 2020a). A vertical transect of benthic $\delta^{13} \mathrm{C}$ (McCave et al., 2008) suggests that the abyssal waters were overlain by $\mathrm{CP}$ waters, separated by pronounced stratification near $\sim 3500-4000 \mathrm{~m}$ water depth. In part, the CP waters stemmed from North Atlantic Deep Water. Their apparent ventilation age 3500 years probably came close to the values found in the southern South Atlantic. East of New Zealand the CP waters entered the deep western Pacific and spread up to the subpolar North Pacific, where LGM ${ }^{14} \mathrm{C}$ ventilation ages reached $\sim 3700$ years, possibly occasionally reaching 5000 years (Fig. S2d).
Similar to today, the MOC of the LGM Pacific was shaped by estuarine geometry, probably more weakened than today (Du et al., 2018) and more distinct in the far northwest than in the far northeast. This geometry resulted in an upwelling of old deep waters in the subarctic northwestern Pacific, here leading to a ${ }^{14} \mathrm{C}$ reservoir age of $\sim 1700$ years for surface waters at terminal LGM. On top of the Lower Pacific Deep Waters, we may surmise Upper Pacific Deep Waters that moved toward south (Figs. 10top and 11).

The Pacific deep waters were overlain by Antarctic and Pacific Intermediate Waters (IW) with LGM ${ }^{14} \mathrm{C}$ ventilation ages as low as 1400-1800 years, except for a ice-covered shelf site at the southern tip of Chile with IW ages of 24002900 years, possibly a result of local upwelling of CP waters. In general, however, the low values of Pacific IW are similar to those estimated for South Atlantic IW and likewise reflect a vivid exchange with atmospheric $\mathrm{CO}_{2}$ in their source regions in the Southern Ocean (Skinner et al., 2015).

When entering and crossing the entrance sill to the marginal South China Sea the "young" IW were mixed with "old" CP waters entrained from below, here leading to ${ }^{14} \mathrm{C}$ ventilation ages of 2600-3450 years (Figs. 9 and S2d). The LGM South China Sea was shaped by an estuarine-style overturning system marked by major upwelling near its distal end in the far southwest (Wang et al., 1999). This upwelling led to planktic ${ }^{14} \mathrm{C}$ reservoir ages as high as 1200 1800 years, values rarely found elsewhere in surface waters of low latitudes.

Our widely spaced distribution pattern of 18 open-ocean ${ }^{14} \mathrm{C}$ ventilation ages (plus four values based on paired wood chunks) in Figs. 10 and 11 agrees only in part with the circulation patterns suggested by the much larger data sets of ${ }^{14} \mathrm{C}$ ventilation ages compiled by Skinner et al. (2017) and Zhao et al. (2018). Several features in Figs. 10 and 11 directly deviate, e.g., the ages we derive for the North Atlantic and mid-depth Pacific. These deviations may be linked to both the different derivation of our ${ }^{14} \mathrm{C}$ ventilation age estimates and the details of our calendar-year chronology now based on the narrow-standing suite of ${ }^{14} \mathrm{C}$ plateau boundary ages. The quality of our ${ }^{14} \mathrm{C}$ reservoir ages of surface waters also controls the "apparent" ventilation age of deep waters, as it results from direct addition of the short-term average ${ }^{14} \mathrm{C}$ age of a planktic ${ }^{14} \mathrm{C}$ plateau to a paired, i.e., coeval benthic, ${ }^{14} \mathrm{C}$ age (formed during the time of benthic foraminiferal growth, somewhat after the actual time of deep-water formation).

\subsubsection{Major features of meridional overturning circulation during early HS-1 (Fig. 10)}

Near the onset of deglacial Heinrich Stadial 1 (HS-1; 18$14.7 \mathrm{cal} \mathrm{ka}$ ) major shifts in ${ }^{14} \mathrm{C}$ ventilation age suggest some short-lasting but fundamental changes in the circulation geometry of the deep ocean, a central theme of marine paleoclimate research (lower panel of Figs. 10, 11, and S2a, b). Deep waters in the eastern Nordic Seas, west of the Azores Islands, 

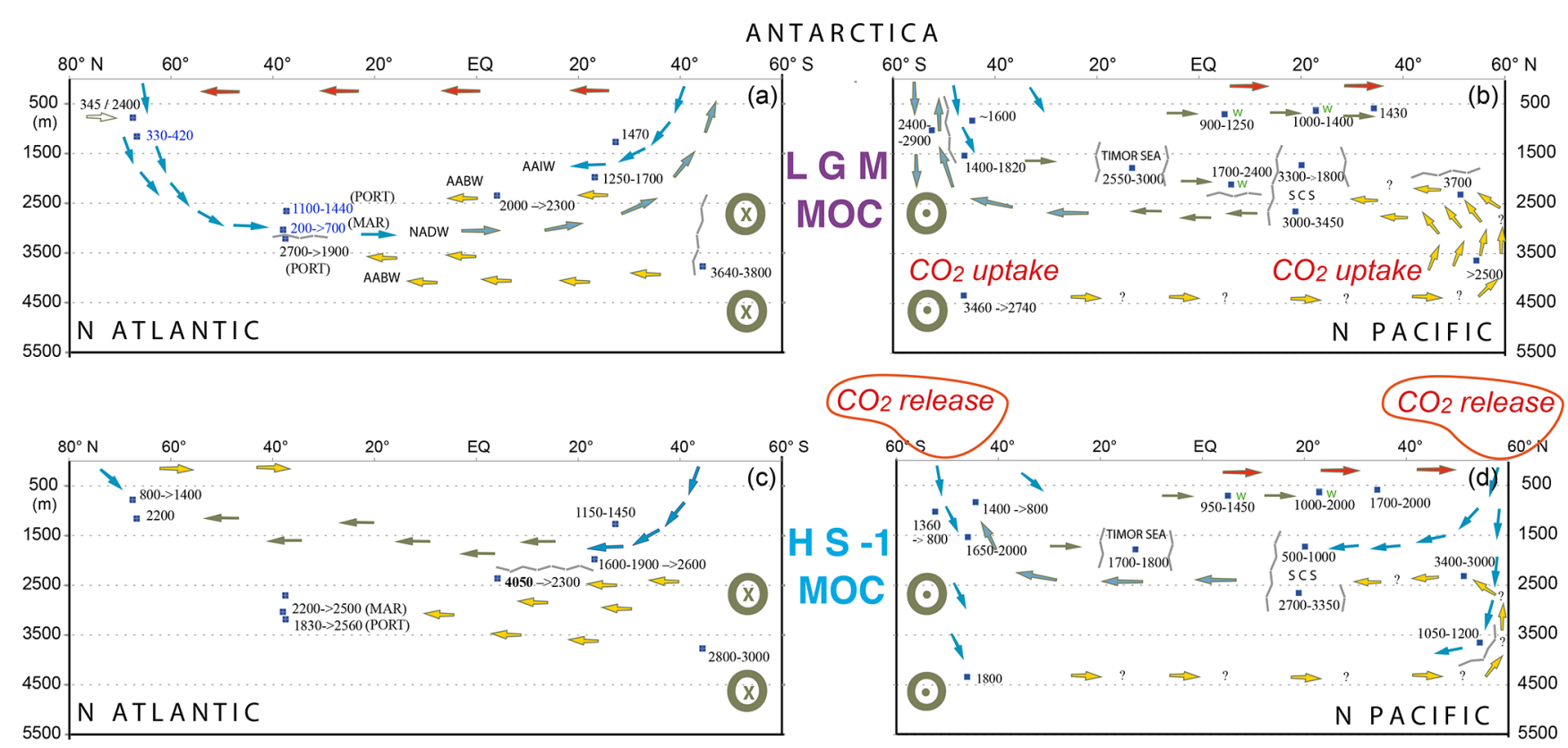

Figure 10. The 2D transects of the geometries of global ocean MOC. Arrows (blue is high ventilation, and yellow is poor ventilation) suggest average deep and intermediate water currents that follow the gradient from low to high benthic ventilation ages based on paired planktic ${ }^{14} \mathrm{C}$ reservoir ages derived by means of a ${ }^{14} \mathrm{C}$ plateau tuning technique (Sarnthein et al., 2013; Balmer et al., 2018; Küssner et al., 2020a). At some Pacific sites reservoir ages are based on paired ${ }^{14} \mathrm{C}$ ages of planktic foraminifera and wood chunks (marked by a green "w"; Sarnthein et al., 2015; Zhao and Keigwin, 2018; Rafter et al., 2018). Red arrows suggest poleward warm surface water currents. Zigzagging lines indicate major frontal systems separating counter rotating ocean currents (e.g., west of Portugal and north of MD07-307; following Skinner et al., 2014). (a, b) Late LGM circulation geometry (21-18.7 cal ka) that is largely similar to today. Note the major east-west gradient of ventilation ages in the central North Atlantic between Portugal (PORT) and the Mid-Atlantic Ridge west of the Azores (MAR). (c, d) HS-1 benthic ventilation ages reveal a short-lasting MOC reversal leading to Atlantic-style overturning in the subpolar North Pacific and coeval Pacific-style stratification in the northern North Atlantic, with seesaw-style reversals of global MOC at the onset and end of early HS-1 (first proposed by Broecker et al., 1985, albeit for LGM times). Increased ventilation ages reflect enhanced uptake of dissolved carbon in the LGM deep ocean (Sarnthein et al., 2013), major drops suggest major degassing of $\mathrm{CO}_{2}$ from both the deep Southern Ocean and North Pacific during early HS-1. SCS is the South China Sea. AABW is Antarctic Bottom Water. AAIW is Antarctic Intermediate Water. NADW is North Atlantic Deep Water. Small arrows within age numbers reflect temporal trends. Many arrows are speculative, using circumstantial evidence of benthic $\delta^{13} \mathrm{C}$ records and local Coriolis forcing at high-latitude sites per analogy to modern scenarios. Location of sediment cores are given in Fig. 7, and short-term variations in planktic and benthic ${ }^{14} \mathrm{C}$ reservoir and ventilation age are given in Fig. S2 and Table 3.

and off northern Brazil show a rapid rise to high ${ }^{14} \mathrm{C}$ ventilation ages of $\sim 2000-2500$ years and up to 4000 years off Brazil, values that give the first proof of a brief switch from "anti-estuarine" to "estuarine" circulation that governed the central North Atlantic and Norwegian Sea during early HS-1. This geometry continued - except for a brief but marked and widespread event of recurring NADW formation near $15.2 \mathrm{ka}$ - until the very end of HS- 1 near 14.5 ka (Fig. S2a; Muschitiello et al., 2019). The MOC switch from LGM to HS-1 is in line with changes depicted in paired benthic $\delta^{13} \mathrm{C}$ data (Sarnthein et al., 1994), but not confirmed by the coeval $\varepsilon_{\mathrm{Nd}}$ record that suggests a constant source of "mid-depth waters", with the $\delta^{13} \mathrm{C}$ drop being simply linked to a higher age (Howe et al., 2018).

Conversely, benthic ${ }^{14} \mathrm{C}$ ventilation ages in the northeastern North Pacific (Site MD02-2489) show a coeval and distinct but brief minimum of 1050-1450 years near 3640 m w.d. during early HS-1 ( 18.1-16.8 ka; Figs. 10,
11, and S2d). This minimum was produced by extremely small benthic-planktic age differences of 350-650 years and provides robust evidence for a millennial-scale event of deep-water formation, which has flushed the northeastern North Pacific down to more than $3640 \mathrm{~m}$ w.d. (Gebhardt et al., 2008; Sarnthein et al., 2013; Rae et al., 2014). Similar circulation geometries were reported for the Pliocene (Burls et al., 2017). "Young" Upper North Pacific Deep Waters (North Pacific Intermediate Waters sensu Gong et al., 2019) then penetrated as a "western boundary current" far to the south, up to the northern continental margin of the South China Sea (Figs. 9b, 11, and S2d). The short-lasting North Pacific regime of anti-estuarine overturning was similar to that we find in the modern and LGM Atlantic and, most interesting, simultaneous with the Atlantic's estuarine episode.

Recent data on benthic-planktic ${ }^{14} \mathrm{C}$ age differences (Du et al., 2018) precisely recover our results in a core at $\sim$ 680 m w.d. off southern Alaska. However, they do not de- 


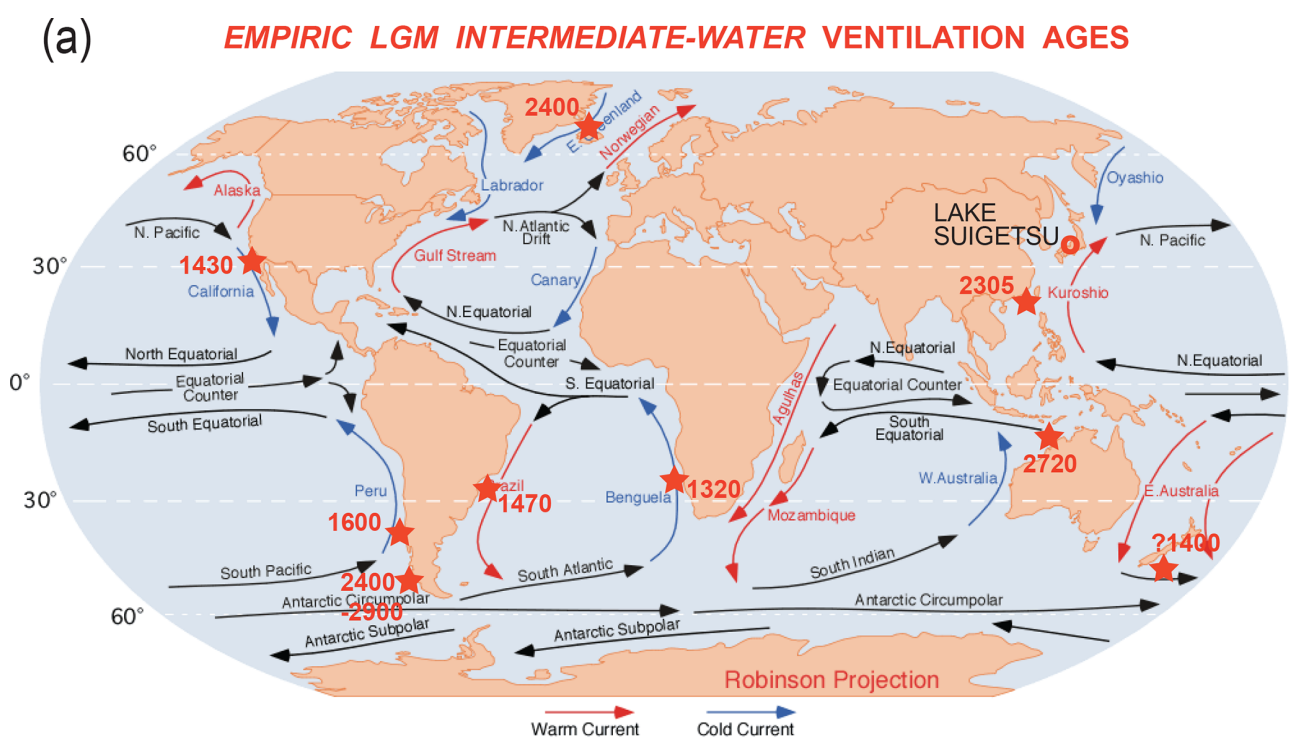

(b) EMPIRIC LGM DEEP-WATER VENTILATION AGES

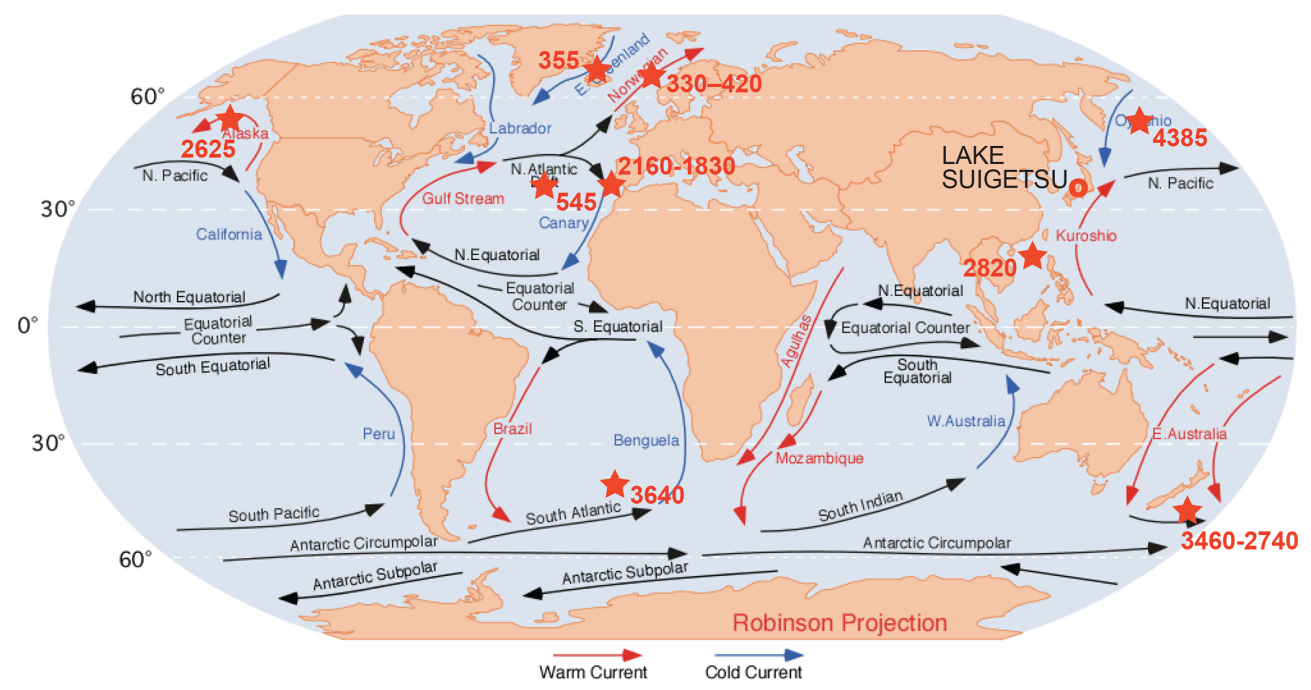

Figure 11. Global distribution of ${ }^{14} \mathrm{C}$ reservoir ages obtained (a) for late LGM intermediate waters (100-1800 m w.d.) and (b) for LGM deep waters (> 1800 m w.d., including Site GIK 23074 at 1157 m in the Norwegian Sea).

pict the "young" deep waters at their Site U1418 at $3680 \mathrm{~m}$ w.d., as corroborated by a paired authigenic $\varepsilon_{\mathrm{Nd}} \max -$ imum suggesting a high local bottom water age nearby. We assume that the amazing difference in local deep-water ventilation ages is due to small-scale differences in the effect of Coriolis forcing at high latitudes between a site located directly at the base of the Alaskan continental margin (U1418; Fig. 10b) and that on the distal Murray Sea Mount in the "open" Pacific (MD02-2489; Figs. 7 and 11), which probably has been washed by a plume of newly formed North Pacific deep waters probably stemming from the Bering and/or Okhotsk Seas. In contrast, the incursion of almost 3000 year old deep waters from the Southern Ocean has continued along the continental margin all over HS-1. In summary we may conclude that the geometry of ocean MOC was briefly reversed in the "open" North Pacific over almost 1500 years during HS-1, far deeper than suggested by previous authors (e.g., Okazaki et al., 2012; Gong et al., 2019) but similar to changes in geometry first proposed by Broecker et al. (1985) for an LGM ocean.

\subsubsection{Deep-ocean DIC inventory}

Apart from the changing geometries in ocean MOC during LGM and HS-1, the global set of ${ }^{14} \mathrm{C}$ plateau-based (and hence refined) estimates of apparent ${ }^{14} \mathrm{C}$ ventilation 
ages (Fig. 10) has ultimately also revealed new insights into glacial-to-deglacial changes in deep-ocean DIC inventories (Sarnthein et al., 2013; Skinner et al., 2019). On the basis of GLODAP data (Key et al., 2004), any drop in ${ }^{14} \mathrm{C}$ concentration (i.e., any rise in average ${ }^{14} \mathrm{C}$ ventilation age) of modern deep waters is tied linearly to a rise of carbon (DIC) dissolved in deep ocean waters below $\sim 2000 \mathrm{~m}$, making for $1.22 \mathrm{mmolC} /-1 \%{ }^{14} \mathrm{C}$. By and large, GCM and box model simulations of Chikamoto et al. (2012) and Wallmann et al. (2016) suggest that this ratio may also apply to LGM deep-water circulation, when apparent ${ }^{14} \mathrm{C}$ ventilation ages in the Southern Ocean increased significantly (from 2400 up to $\sim 3800$ years), thermohaline circulation was accordingly more sluggish, and transit times of deep waters extended. Accordingly, a "back-of-the-envelope" calculation of LGM ventilation age averages in the global deep ocean suggests an additional carbon absorption of 730-980 Gt (Sarnthein et al., 2013). This estimate can easily accommodate the glacial transfer of $\sim 200 \mathrm{GtC}$ from the atmosphere and biosphere and may also explain $200-450 \mathrm{Gt} C$ that was most probably removed from glacial Atlantic and Pacific intermediate waters. These estimates offer an independent evaluation of ice core-based data, other proxies, and model-based data on past changes in the global carbon cycle (e.g., Menviel et al., 2018).

\section{Some conclusions and perspectives}

- Despite some analytical scatter, ${ }^{14} \mathrm{C}$ ages for the top and base of Lake Suigetsu-based atmospheric ${ }^{14} \mathrm{C}$ plateaus and coeval planktic ${ }^{14} \mathrm{C}$ plateaus do not present statistical "outliers" but instead show real age estimates that are reproduced by tree-ring-based ${ }^{14} \mathrm{C}$ ages over the interval $10-13$ cal ka and further back.

- Hulu Cave U/Th model-based ages of ${ }^{14} \mathrm{C}$ plateau boundaries of the Suigetsu atmospheric ${ }^{14} \mathrm{C}$ record appear to be superior to those derived from microscopybased varve counts only, since U/Th model-based ages match far more closely the age when now deduced from XRF-based varve counts for the tie point of lower plateau boundary $2 \mathrm{~b}$, a test case in the early deglacial, and for the age assigned to the Laschamp event prior to the LGM.

- During deglacial times, we show that several atmospheric ${ }^{14} \mathrm{C}$ plateaus paralleled a rise in air-sea gas exchange and in turn distinct changes in ocean MOC. Changes in cosmogenic ${ }^{14} \mathrm{C}$ production rarely provide a complete explanation for the plateaus identified in the Suigetsu ${ }^{14} \mathrm{C}$ data under discussion.

- In total, ${ }^{14} \mathrm{C}$ plateau boundaries in the range now provide a suite of $\sim 30$ age tie points to establish - like chronological ladder rungs - a robust global age control for deep-sea sediment sections and global strati- graphic correlations of last glacial to deglacial climate events, 29-10 cal ka. U/Th model ages confine the calibrated age uncertainty of Suigetsu plateau boundaries assigned halfway between two ${ }^{14} \mathrm{C}$ ages nearby inside and outside a plateau's scatter band to less than \pm 50 to \pm 70 years. Nevertheless, stratigraphic gaps may hamper the accurate tuning of planktic ${ }^{14} \mathrm{C}$ plateaus to their atmospheric equivalents and result in major discrepancies.

- The difference in ${ }^{14} \mathrm{C}$ age between coeval atmospheric and planktic ${ }^{14} \mathrm{C}$ plateaus presents a robust tracer of planktic ${ }^{14} \mathrm{C}$ reservoir ages and shows their high temporal and spatial variability for the LGM and HS-1 that is now established for 18 and 20 sediment sites, respectively.

- Paired reservoir ages obtained from different planktic species document the local distribution patterns of different surface water masses and prevailing foraminiferal habitats at different seasons are still insufficiently considered in model simulations.

- New, more robust deep-water ${ }^{14} \mathrm{C}$ ventilation ages, derived on the basis of our robust planktic ${ }^{14} \mathrm{C}$ reservoir ages, reveal geometries of LGM overturning circulation similar to those of today. In contrast, ${ }^{14} \mathrm{C}$ ventilation ages of early HS-1 suggest an almost 1500 -year event of widely reversed circulation patterns marked by deepwater formation and brief flushing of the northern North Pacific and estuarine circulation geometry in the northern North Atlantic.

- Increased glacial ${ }^{14} \mathrm{C}$ ventilation ages and carbon (DIC) inventories of ocean deep waters suggest an LGM drawdown of about $850 \mathrm{GtC}$ into the deep ocean. Starting with HS-1 a drop of ventilation age suggests carbon released to the atmosphere (Sarnthein et al., 2013).

- Site-specific comparisons of planktic and model-based reservoir age estimates highlight the need for further model refinements to make them better reflect the real complex patterns of ocean circulation, including seasonality.

Data availability. Published primary radiocarbon data of all sites are available at PANGAEA. The ${ }^{14} \mathrm{C}$ data of five marine sediment cores still under publication by Küssner et al. (2020a) and Ausin et al. (2020a; see the caption of Fig. S2) are deposited at PANGAEA under https://doi.org/10.1594/PANGAEA.922671 (Küssner et al. 2020b) and https://doi.pangaea.de/10.1594/PANGAEA. 921812 (Ausín et al., 2020b).

Supplement. The supplement related to this article is available online at: https://doi.org/10.5194/cp-16-2547-2020-supplement. 
Author contributions. All authors contributed data and valuable suggestions to write up this synthesis. MS and PG designed the outline of the manuscript. KK, BA, TE, and MS provided new marine ${ }^{14} \mathrm{C}$ records in addition to records previously published. GS displayed the details of Suigetsu varve counts. RM provided a ${ }^{10} \mathrm{Be}-$ based ${ }^{14} \mathrm{C}$ record and plots of raw ${ }^{14} \mathrm{C}$ data sets of Suigetsu und Hulu Cave. Discussions amongst PG, RM, GS, and MS served to select U/Th-based model ages at the best possible timescale. JM streamlined the sections on data-model intercomparison.

Competing interests. The authors declare that they have no conflict of interest.

Acknowledgements. We owe sincere thanks for plenty of stimulations to the 23rd International Radiocarbon Conference in Trondheim, in particular to Marie-José Nadeau, and to the IPODS-OC3 workshop in Cambridge UK, 2018, convened by Andreas Schmittner and Luke Skinner. Moreover, we thank for most valuable basic discussions with Richard Staff, Glasgow, John Southon, Irvine CA, and Martin Butzin, AWI Bremerhaven, who kindly helped us to discuss the comparison of his model results, and Sebastian Beil, Kiel, for computer assistance. Over the last three years, Gesine Mollenhauer measured with care hundreds of supplementary ${ }^{14} \mathrm{C}$ ages in her MICADAS laboratory at AWI Bremerhaven. This study obtained long lasting special support from Ralf Tiedemann and his colleagues at the AWI Bremerhaven.

Financial support. This research has been supported by the Alfred Wegener Institute Helmholtz Centre for Polar and Marine Research.

Review statement. This paper was edited by André Paul and reviewed by two anonymous referees.

\section{References}

Abé-Ouchi, A.: Deglaciation and DO-like experiments with MIROC AOGCM, Workshop on "Ocean circulation and carbon cycling during the last deglaciation: Global synthesis", Cambridge, UK, 6-9 September 2018, IPODS/OC3, 2018.

Adkins, J. F. and Boyle, E. A.: Changing atmospheric $\Delta^{14} \mathrm{C}$ and the record of paleoventilation ages, Paleoceanography, 12, 337-344, 1997.

Adolphi, F., Bronk Ramsey, C., Erhardt, T., Edwards, R. L., Cheng, H., Turney, C. S. M., Cooper, A., Svensson, A., Rasmussen, S. O., Fischer, H., and Muscheler, R.: Connecting the Greenland ice-core and $\mathrm{U} / \mathrm{Th}$ timescales via cosmogenic radionuclides: testing the synchroneity of Dansgaard-Oeschger events, Clim. Past, 14, 1755-1781, https://doi.org/10.5194/cp-14-1755-2018, 2018.

Alves, E. Q., Macario, K., Ascough, P., and Bronk Ramsey, C.: The worldwide marine radiocarbon reservoir effect: definitions, mechanisms, and prospects, Rev. Geophys., 56, RG000588, https://doi.org/10.1002/2017RG000588, 2018.
Alveson, E. Q.: Radiocarbon in the Ocean, EOS, 99, EO095429, https://doi.org/10.1029/2018EO095429, 2018.

Ausin, B., Sarnthein, M., and Haghipour, N.: Glacial-to-deglacial reservoir and ventilation ages at the southwest Iberian continental margin, Quaternary Sci. Rev., in review, 2020a.

Ausín, B., Sarnthein, M., Haghipour, N., and Eglinton, T. I.: Surface ocean reservoir ages in the SW Iberian margin from 11 to $23 \mathrm{kyr}$, PANGAEA, https://doi.org/10.1594/PANGAEA.921812, $2020 \mathrm{~b}$.

Balmer, S. and Sarnthein, M.: Planktic ${ }^{14} \mathrm{C}$ plateaus, a result of short-term sedimentation pulses?, Radiocarbon, 59, 33-43, https://doi.org/10.1017/RDC.2016.100, 2016.

Balmer, S. and Sarnthein, M.: Glacial-to-deglacial changes in North Atlantic melt-water advection and deep-water formation - Centennial-to-millennial-scale ${ }^{14} \mathrm{C}$ records from the Azores Plateau, Geochim. Cosmochim. Ac., 236, 399-415, https://doi.org/10.1016/j.gca.2018.03.001, 2018.

Balmer, S., Sarnthein, M., Mudelsee, M., and Grootes, P. M.: Refined modeling and ${ }^{14} \mathrm{C}$ plateau tuning reveal consistent patterns of glacial and deglacial ${ }^{14} \mathrm{C}$ reservoir ages of surface waters in low-latitude Atlantic, Paleoceanography, 31, PA002953, https://doi.org/10.1002/2016PA002953, 2016.

Berger, W. H. and Keir, R. S.: Glacial-Holocene changes in atmospheric $\mathrm{CO}_{2}$ and the deep-sea record, in: Climate Processes and Climate Sensitivity, edited by: Hansen, J. E. and Takahashi, T., American Geophysical Union, Washington, DC, USA, 337-351, 1984.

Bostock, H. C., Barrows, T. T., Carter, L., Chase, Z., Cortese, G., Dunbar, G. B., Ellwood, M., Hayward, B., Howard, W., Neil, H. I., Noble, T. L., Mackintosh, A., Moss, P. T., Moy, A. D., White, D., Williams, M. J. M., and Armand, L. K.: A review of the Australian-New Zealand sector of the Southern Ocean over the last 30ka (Aus-INTIMATE project), Quaternary Sci. Rev., 74, 35-57, 2013.

Broecker, W. S, Peteet, D. M., and Rind, D.: Does the oceanatmosphere system have more than one stable mode of operation?, Nature, 315, 21-26, https://doi.org/10.1038/315021a0, 1985

Broecker, W. S., Barker, S., Clark, E., Hajdas, I., Bonani, G., and Stott, L.: Ventilation of the Glacial deep Pacific Ocean, Science, 306, 1169-1172, 2004.

Bronk Ramsey, C., Staff, R. A., Bryant, C. L., Brock, F., Kitagawa, H., van der Plicht, J., Schlolaut, G., Marshall, M. H., Brauer, A., Lamb, H. F., Payne, R. L., Tarasov, P. E., Haraguchi, T., Gotanda, K., Yonenobu, H., Yokoyama, Y., Tada, R., and Nakagawa, T.: A complete terrestrial radiocarbon record for 11.2 to $52.8 \mathrm{kyr}$ B.P., Science, 338, 370-374, 2012.

Bronk Ramsey, C., Heaton, T. J., Schlolaut, G., Staff, R. A., Bryant, C. L., Lamb, H. F., Marshall, M. H., and Nakagawa, T.: Reanalysis of the atmospheric radiocarbon calibration record from Lake Suigetsu, Japan, Radiocarbon, 62, 989-999, https://doi.org/10.1017/RDC.2020.18, 2020.

Burke, A. and Robinson, L. F.: The Southern Ocean's role in carbon exchange during the last deglaciation, Science, 335, 557-561, 2012.

Burls, N. J., Fedorov, A. V., Sigman, D. M., Jaccard, S. L., Tiedemann, R., and Haug, G. H.: Active Pacific meridional overturning circulation (PMOC) during the warm Pliocene, Sci. Adv., 3, e1700156, https://doi.org/10.1126/sciadv.1700156, 2017. 
Butzin, M., Prange, M., and Lohmann, G.: Readjustment of glacial radiocarbon chronologies by self-consistent three-dimensional ocean circulation modeling, Earth Planet Sci. Lett., 317, 177184, 2012.

Butzin, M., Köhler, P., and Lohmann, G.: Marine radiocarbon reservoir age simulations for the past 50,000 years, Geophys. Res. Lett., 44, 8473-8480, https://doi.org/10.1002/2017GL074688, 2017.

Butzin, M., Heaton, T. J., Köhler, P., and Lohmann, G.: A short note on marine reservoir age simulations used in INTCAL20, Radiocarbon, 62, 865-871, https://doi.org/10.1017/RDC.2020.9, 2020.

Chen, T., Robinson, L. F., Burke, A., Southon, J., Spooner, P., Morris, P. J., and Ng, H. C.: Synchronous centennial abrupt events in the ocean and atmosphere during the last deglaciation, Science, 349, 1537-1541, 2015.

Cheng, H., Edwards, R. L., Southon, J., Matsumoto, K., Feinberg, J. M., Sinha, A., Zhou, W., Li, H., Li, X., Xu, Y., Chen, S., Tan, M., Wang, Q., Wang, Y., and Ning, Y.: Atmospheric ${ }^{14} \mathrm{C} /{ }^{12} \mathrm{C}$ changes during the last glacial period from Hulu Cave, Science, 362, 1293-1297, 2018.

Chikamoto, M. O., Abe-Ouchi, A., Oka, A., Ohgaito, R., and Timmermann, A.: Quantifying the ocean's role in glacial $\mathrm{CO}_{2}$ reductions, Clim. Past, 8, 545-563, https://doi.org/10.5194/cp-8-5452012, 2012.

Cook, M. S. and Keigwin, L. D.: Radiocarbon profiles of the NW Pacific from the LGM and deglaciation: Evaluating ventilation metrics and the effect of uncertain surface reservoir ages, Paleoceanography, 30, 174-195, 2015.

Davies, S. M., Abbott, P. M., Meara, R. H., Pearce, N. J. G., Austin, W. W. N., Chapman, M. R., Svensson, A., Bigler, M., Rasmussen, T. I., Rasmussen, S. O., and Farmer, E. J.: A North Atlantic tephrostratigraphical framework for $130-60 \mathrm{ka} \mathrm{b} 2 \mathrm{k}$ : New tephra discoveries, marine based correlations, and future challenges, Quaternary Sci. Rev., 106, 101-121, 2014.

Du, J., Haley, B. A., Mix, A. C., Walczak, M. H., and Praetorius, S. K.: Flushing of the deep Pacific Ocean and the deglacial rise of atmospheric $\mathrm{CO}_{2}$ concentrations, Nat. Geosci., 11, 749-755, 2018.

Ferrari, R., Jansen, M. F., Adkins, J. F., Burke, A., Stewart, A. L., and Thompson, A. F.: Antarctic sea ice control on ocean circulation in present and glacial climates, P. Natl. Acad. Sci. USA, 111, 8753-8758, 2014.

Franke, J., Schulz, M., Paul, A., and Adkins, J. F.: Assessing the ability of the ${ }^{14} \mathrm{C}$ projection-age method to constrain the circulation of the past in a 3-D ocean model, Geochem. Geophy. Geosy., 9, Q08003, https://doi.org/10.1029/2008GC001943, 2008.

Gebbie, G.: How much did Glacial North Atlantic Water shoal?, Paleoceanography, 29, 190-209, https://doi.org/10.1002/2013PA002557, 2014.

Gebhardt, H., Sarnthein, M., Kiefer, T., Erlenkeuser, H., Schmieder, F., and Röhl, U.: Paleonutrient and productivity records from the subarctic North Pacific for Pleistocene glacial terminations $\mathrm{I}$ to $\mathrm{V}$, Paleoceanography 23, 1-21, https://doi.org/10.1029/2007PA001513, 2008.

Gong, S., Lembke-Jene, L., Lohmann, G., Knorr, G., Tiedemann, R., Zou, J. J., and Shi, X. F.: Enhanced North Pacific deep-ocean stratification by stronger intermediate water formation during Heinrich Stadial 1, Nat. Commun., 10, 656, https://doi.org/10.1038/s41467-019-08606-2, 2019.

Grootes, P. M. and Sarnthein, M.: Marine ${ }^{14} \mathrm{C}$ reservoir ages oscillate, PAGES News, 143, 18-19, 2006.

Grootes P. M. and Stuiver, M.: Oxygen 18/16 variability in Greenland snow and ice with 1000 to 100000 year time resolution, J. Geophys. Res.-Oceans, 102, 26455-26470, 1997.

Hain, M. P., Sigman, D. M., and Haug, G. H.: Distinct roles of the Southern Ocean and North Atlantic in the deglacial atmospheric radiocarbon decline, Earth Planet. Sci. Lett., 394, 198-208, 2014.

Howe, J. N. W., Piotrowski, A. M., Noble, T. L., Mulitza, S., Chiessi, C. M., and Bayon, G.: North Atlantic deep-water production during the last glacial maximum, Nat. Commun., 7, 11765, https://doi.org/10.1038/ncomms11765, 2016.

Howe, J. N. W., Huang, K.-F., Oppo, D. W., Chiessi, C. M., Mulitza, S., Blusztajn, J., and Piotrowski, A .M.: Similar mid-depth Atlantic water mass provenance during the Last Glacial Maximum and Heinrich Stadial 1, Earth Planet. Sci. Lett., 490, 51-61, 2018.

Jonkers, L. and Kučera, M.: Quantifying the effect of seasonal and vertical habitat tracking on planktonic foraminifera proxies, Clim. Past, 13, 573-586, https://doi.org/10.5194/cp-13-5732017, 2017.

Kawamura, K., Parrenin, F., Lisiecki, L., Uemura, R., Vimeux, F., Severinghaus, J. P., Hutterli, M. A., Nakazawa, T., Aoki, S., Jouzel, J., Raymo, M. E., Matsomoto, K., Nakata, H., Fujita, S., Goto-Azuma, K, Fujii, Y., and Watanabe, O.: Northern Hemisphere forcing of climatic cycles in Antarctica over the past 360,000 years, Nature, 448, 912-916, https://doi.org/10.1038/nature06015, 2007.

Keigwin, L. D. and Swift, S. A.: Carbon isotope evidence for a northern source of deep water in the glacial western North Atlantic, P. Natl. Acad. Sci. USA, 114, 2831-2835, 2017.

Key, R. M., Kozyr, A., Sabine, C. L., Lee, K., Wanninkhof, R., Bullister, J. L., Feely, R. A., Millero, F. J., Mordy, C., and Peng, T.-H.: A global ocean carbon climatology: Results from Global Data Analysis Project (GLODAP), Global Biogeochem. Cy., 18, GB4031, https://doi.org/10.1029/2004GB002247, 2004.

Kong, X., Wang, Y., Wu, J., Cheng, H., Edwards, R. L., and Wang, $\mathrm{X}$.: Complicated responses of stalagmite $\delta^{13} \mathrm{C}$ to climate change during the last glaciation from Hulu Cave, Sci. China Ser. D, 48, 2174-2181, 2005.

Küssner, K., Sarnthein, M., Lamy, F., and Tiedemann, R.: High-resolution radiocarbon-based age records trace episodes of Zoophycos burrowing, Mar. Geol., 403, 4856,https://doi.org/10.1016/j.margeo.2018.04.01, 2018.

Küssner, K., Sarnthein, M., Michel, E., Mollenhauer, G., Siani G., and Tiedemann, R.: Glacial-to-deglacial reservoir ages of surface waters in the southern South Pacific, Paleoceanography and Paleoclimate, 47, in review, 2020a.

Küssner, K., Sarnthein, M., Michel, E., Mollenhauer, G., Ronge, T. A., Siani, G., and Tiedemann, R.: Glacial to deglacial reservoir ages of surface waters in the southern South Pacific, PANGAEA, https://doi.org/10.1594/PANGAEA.922671, 2020b.

Lascu, I., Feinberg, J. M., Dorale, J. A., Cheng, H., and Edwards, R. L.: Age of the Laschamp excursion determined by U-Th dating of a speleothem geomagnetic record from North America, Geology, 44, 139-142, https://doi.org/10.1130/G37490.12016.

Lindsay, C. M., Lehman, S. J., Marchitto, T. M., and Ortiz, J. D.: The surface expression of radiocarbon anomalies near Baja Cal- 
ifornia during deglaciation, Earth Planet. Sci. Lett., 422, 67-74, 2015.

Lippold, J., Gutjahr, M., Blaser, P., Christner, E., de CavalhoFereira, M. L., Mulitza, S., Christl, M., Wormbach, F., Böhm, E., Antz, B., Cartapanis, O., Vogel, H., and Jaccard, S. L.: Deep-water provenance and dynamics of the (de)glacial Atlantic meridional overturning circulation, Earth Planet. Sci. Lett., 445, 68-78, 2016.

Lisiecki, L. E. and Stern, J. V.: Regional and global benthic $\delta^{18} O$ stacks for the last glacial cycle, Paleoceanography, 31, PA003002, https://doi.org/10.1002/2016PA003002, 2016.

Marcott, S. A., Bauska, T. K., Buizert, C., Steig, E. J., Rosen, J. L., Cuffey, K. M., Fudge, T. J., Severinghaus, J. P., Ahn, J., Kalk, M. L., McConnell, J. R., Sowers, T., Taylor, K. C., White, J. W. C., and Brook, E. J.: Centennial-scale changes in the global carbon cycle during the last deglaciation, Nature, 514, 616-619, https://doi.org/10.1038/nature13799, 2014.

Marshall, M., Schlolaut, G., Brauer, A., Nakagawa, T., Staff, R. A., Bronk Ramsey, C., Lamb, H., Gotanda, K., Haraguchi, T., Yokoyama, Y., Yonenobu, H., Tada, R., and SG06 project members: A novel approach to varve counting using $\mu \mathrm{XRF}$ and $\mathrm{X}$ radiography in combination with thin-section microscopy, applied to the Late Glacial chronology from Lake Suigetsu, Japan, Quat. Geochronol., 13, 70-80, 2012.

Matsumoto, K.: Radiocarbon-based circulation age of the world oceans, J. Geophys. Res.-Oceans, 112, C09004, https://doi.org/10.1029/2007JC004095, 2007.

McCave, I. N., Carter, 1., and Hall, I. R.: Glacial-interglacial changes in water mass structure and flow in the SW Pacific Ocean, Quaternary Sci. Rev., 27, 1886-1908, 2008.

Menviel, L., Spence, P., Yu, J., Chamberlain, M. A., Matear, R. J., Meissner, K. J., and England, M. H.: Southern Hemisphere westerlies as a driver of the early deglacial atmospheric $\mathrm{CO}_{2}$ rise, Nat. Commun., 9, 2503, https://doi.org/10.1038/s41467-018-048764, 2018.

Millo, C., Sarnthein, M., and Erlenkeuser, M.: Variability of the Denmark Strait Overflow during the Last Glacial Maximum, Boreas, 35, 50-60, 2006.

Muglia, J., Skinner, L., and Schmittner, A.: Weak overturning circulation and high Southern Ocean nutrient utilization maximized glacial ocean carbon, Earth Planet. Sci. Lett., 496, 47-56, 2018.

Muschitiello, F., D'Andrea, W. J., Schmittner, A., Heaton, T. J., Balascio, N. L., de Roberts, N., Caffee, M. W., Woodruff, T. E., Welten, K. C., Skinner, L. C., Simon, M. H., and Dokken T. M.: Deep-water circulation changes lead North Atlantic climate during deglaciation, Nat. Commun., 10, 1272, https://doi.org/10.1038/s41467-019-09237-3, 2019.

Naughton, F., Costas, S., Gomes, S. D., Desprat, S., Rodrigues, T., Sanchez Goñi, M. F., Renssen, H., Trigo, R., Bronk-Ramsey, C., Oliveira, D., Salgueiro, E., Voelker, A. H. L., and Abrantes, F.: Coupled ocean and atmospheric changes during Greenland stadial 1 in southwestern Europe, Quaternary Sci. Rev., 212, 108120, 2019.

Nydal, R., Lovseth, K., and Skogseth, F. H.: Transfer of bomb ${ }^{14} \mathrm{C}$ to the ocean surface, Radiocarbon, 22, 626-635, 1980.

Okazaki, Y., Sagawa, T., Asahi, H., Horikawa, K., and Onodera, J.: Ventilation changes in the western North Pacific since the last glacial period, Clim. Past, 8, 17-24, https://doi.org/10.5194/cp8-17-2012, 2012.
Paillard, D., Labeyrie, L., and Yiou, P.: Macintosh program performs time-series analysis, Eos, 77, 379, https://doi.org/10.1029/96EO00259, 1996.

Rae, J., Sarnthein, M., Foster, G., Ridgwell, A., Grootes, P. M., and Elliott T.: Deep water formation in the North Pacific and deglacial $\mathrm{CO}_{2}$ rise, Paleoceanography, 29, 645-667, https://doi.org/10.1002/2013PA002570, 2014.

Rae, J. W. B. and Broecker, W.: What fraction of the Pacific and Indian oceans' deep water is formed in the Southern Ocean?, Biogeosciences, 15, 3779-3794, https://doi.org/10.5194/bg-153779-2018, 2018.

Rafter, P. A., Herguera, J.-C., and Southon, J. R.: Extreme lowering of deglacial seawater radiocarbon recorded by both epifaunal and infaunal benthic foraminifera in a wood-dated sediment core, Clim. Past, 14, 1977-1989, https://doi.org/10.5194/cp-14-19772018, 2018.

Raisbeck, G. M., Cauquoin, A., Jouzel, J., Landais, A., Petit, J.-R., Lipenkov, V. Y., Beer, J., Synal, H.-A., Oerter, H., Johnsen, S. J., Steffensen, J. P., Svensson, A., and Yiou, F.: An improved northsouth synchronization of ice core records around the $41 \mathrm{kyr}{ }^{10} \mathrm{Be}$ peak, Clim. Past, 13, 217-229, https://doi.org/10.5194/cp-13217-2017, 2017.

Reimer, P. J., Bard, E., Bayliss, A., Beck, J. W., Blackwell, P. G., Bronk Ramsey, C., Buck, C. E., Cheng, H., Edwards, R. L., and Friedrich, M.: IntCal13 and Marine13 radiocarbon age calibration curves 0-50,000 years cal. BP, Radiocarbon, 55, 1869-1887, 2013.

Reimer, P. J., Austin, W. E. N., Bard, E., et al.: The IntCal20 northern hemisphere radiocarbon calibration curve (0-55 cal kBP), Radiocarbon, 62, 725-757, https://doi.org/10.1017/RDC.2020.41, 2020.

Robinson, L. F., Adkins, J. F., Keigwin, L. D., Southon, J., Fernandez, D.P., Wang, S-L., and Scheirer, D.S.: Radiocarbon variability in the western North Atlantic during the last deglaciation, Science, 310, 1469-1473, 2005.

Ronge, T. A., Tiedemann, R., Lamy, F., Köhler, P., Aloway, B. V., De Pol-Holz, R., Pahnke, K., Southon, J., and Wacker, L.: Radiocarbon constraints on the extent and evolution of the South Pacific glacial carbon pool, Nat. Commun., 7, 11487 , https://doi.org/10.1038/ncomms11487, 2016.

Ronge, T. A., Sarnthein, M., Roberts, J., Lamy, F., and Tiedemann, R.: East Pacific Core PS75/059-2: Glacial-to-deglacial stratigraphy revisited, Paleoceanography and Paleoclimatology, 34, 432435, https://doi.org/10.1029/2019PA003569, 2019.

Sarnthein, M., Winn, K., Jung, S. J., Duplessy, J. C., Labeyrie, L., Erlenkeuser, H., and Ganssen, G.: Changes in east Atlantic deepwater circulation over the last 30,000 years: eight time slice reconstructions, Paleoceanography, 9, 209-267, 1994.

Sarnthein, M., Pflaumann, U., and Weinelt, M.: Past extent of sea ice in the northern North Atlantic inferred from foraminiferal paleotemperature estimates, Paleoceanography, 18, PA000771, https://doi.org/10.1029/2002PA000771, 2003.

Sarnthein, M., Grootes, P. M., Kennett, J. P., and Nadeau, M.: ${ }^{14} \mathrm{C}$ Reservoir ages show deglacial changes in ocean currents and carbon cycle, in: Ocean Circulation: Mechanisms and Impacts Past and Future Changes of Meridional Overturning, edited by: Schmittner, A., Chiang, J. C. H., and Hemming, S. R., American Geophysical Union, Washington, DC, USA, 175-196, 2007. 
Sarnthein, M., Grootes, P. M., Holbourn, A., Kuhnt, W., and Kühn, H.: Tropical warming in the Timor Sea led deglacial Antarctic warming and almost coeval atmospheric $\mathrm{CO}_{2}$ rise by $>500 \mathrm{yr}$, Earth Planet. Sci. Lett., 302, 337-348, 2011.

Sarnthein, M., Schneider, B., and Grootes, P. M.: Peak glacial ${ }^{14} \mathrm{C}$ ventilation ages suggest major draw-down of carbon into the abyssal ocean, Clim. Past, 9, 2595-2614, https://doi.org/10.5194/cp-9-2595-2013, 2013.

Sarnthein, M., Balmer, S., Grootes, P. M., and Mudelsee, M.: Planktic and benthic ${ }^{14} \mathrm{C}$ reservoir ages for three ocean basins, calibrated by a suite of ${ }^{14} \mathrm{C}$ plateaus in the glacial-to-deglacial Suigetsu atmospheric ${ }^{14} \mathrm{C}$ record, Radiocarbon, 57, 129-151, 2015.

Sarnthein, M. and Werner, K.: Early Holocene planktic foraminifers record species-specific ${ }^{14} \mathrm{C}$ reservoir ages in Arctic Gateway, Mar. Micropaleontol., 135, 45-55. https://doi.org/10.1016/j.marmicro.2017.07.002, 2018.

Schlolaut, G., Staff, R. A., Marshall, M. H., Brauer, A., Bronk Ramsey, C., Lamb, H. F., and Nakagawa, T.: Microfacies analysis of the Lake Suigetsu (Japan) sediments from $\sim 50$ to $\sim 10 \mathrm{ka} \mathrm{BP}$ and an extended and revised varve based chronology, Quaternary Sci. Rev., 200, 351-366, 2018.

Schmittner, A. and Lund, D. C.: Early deglacial Atlantic overturning decline and its role in atmospheric $\mathrm{CO}_{2}$ rise inferred from carbon isotopes $\left(\delta^{13} \mathrm{C}\right)$, Clim. Past, 11, 135-152, https://doi.org/10.5194/cp-11-135-2015, 2015.

Schroeder, J., Holbourn, A., Küssner, K., and Kuhnt, W.: Hydrological variability in the southern Makassar Strait during the last glacial termination, Quaternary Sci. Rev., 154, 143-156, 2016.

Sessford, E. G., Jensen, M. F., Tisserand, A. A., Muschitiello, F., Dokken, T., Nisancioglu, K. H., and Jansen, E.: Consistent fluctuations on intermediate water temperature off the coast off Greenland and Norway suring Dansgaard-Oeschger events, Quaternary Sci. Rev., 223, 1-17, 2019.

Sherriff-Tadano, S., Abe-Ouchi, A., Yoshimori, M., Oka, A., and Chan, W.-L.: Influence of glacial ice sheets on the Atlantic meridional overturning circulation through surface wind change, Clim. Dynam., 50, 2881-2903, 2017.

Siani, G., Michel, E., De Pol-Holz, R., De Vries, T., Lamy, F., Carel, M., Isguder, G., Dewilde, F., and Lourantou, A.: Carbon isotope records reveal precise timing of enhanced Southern Ocean upwelling during the last deglaciation, Nat. Commun., 4, 2758, https://doi.org/10.1038/ncomms3758, 2013.

Sikes, E. L. and Guilderson, T. P.: Southwest Pacific Ocean surface reservoir ages since the last deglaciation: Circulation insights from multiple-core studies, Paleoceanography, 31, 298310, https://doi.org/10.1002/2015PA002855, 2016.

Simstich, J., Sarnthein, M., and Erlenkeuser, H.: Paired $\delta^{18} \mathrm{O}$ signals of Neogloboquadrina pachyderma (s) and Turborotalita quinqueloba show thermal stratification structure in Nordic Seas, Mar. Micropaleontol., 912, 1-19, 2003.

Skinner, L. C., Fallon, S., Waelbroeck, C., Michel, E., and Barker, S.: Ventilation of the deep Southern Ocean and deglacial $\mathrm{CO}_{2}$ rise, Science, 328, 1147-1151, 2010.

Skinner, L. C., Waelbroeck, C., Scrivner, A. E., and Fallon, S.J.: Radiocarbon evidence for alternating northern and southern sources of ventilation of the deep Atlantic carbon pool during the last deglaciation, P. Natl. Acad. Sci. USA, 111, 5480-5484, 2014.
Skinner, L., McCave, I. N., Carter, L., Fallon, S., Scrivner, A. E., and Primeau, F.: Reduced ventilation and enhanced magnitude of the deep Pacific carbon pool during the last glacial period, Earth Planet. Sci. Lett., 411, 45-52, 2015.

Skinner, L. C., Primeau, F., Freeman, E., de la Fuente, M., Goodwin, P. A., Gottschalk, J., Huang, E., McCave, I. N., Noble, T. L., and Scrivner, A. E.: Radiocarbon constraints on the glacial ocean circulation and its impact on atmospheric $\mathrm{CO}_{2}$, Nat. Commun., 8, 16010, https://doi.org/10.1038/ncomms16010, 2017.

Skinner, L. C., Muschitiello, F., and Scrivner, A. E.: Marine reservoir age variability over the last deglaciation: Implications for marine carbon cycling and prospects for regional radiocarbon calibrations, Paleoceanography and Paleoclimate, 34, PA003667, https://doi.org/10.1029/2019PA003667, 2019.

Southon, J., Noronha, A. L., Cheng, H., Edwards, R. L., and Wang, Y.: A high-resolution record of atmospheric ${ }^{14} \mathrm{C}$ based on Hulu Cave speleothem H82, Quaternary Sci. Rev., 33, 32-41, 2012.

Steffensen, J. P., Andersen, K. K., Bigler, M., Clausen, H. B., DahlJensen, D., Fischer, H., Goto-Azuma, K., Hansson, M., Johnsen, S. J., Jouzel, J., Masson-Delmotte, V., Popp, T., Rasmussen, S. O., Röthlisberger, R., Ruth, U., Stauffer, B., Siggaard-Andersen, M. L., Sveinsbjörnsdottir, A. E., Svensson, A., and White, J. W. C.: High-Resolution Greenland Ice Core Data Show Abrupt Climate Change Happens in Few Years, Science, 321, 680-684, https://doi.org/10.1126/science.1157707, 2008.

Stern, J. V. and Lisiecki, L. E.: North Atlantic circulaton and reservoir age changes over the past 41,000 years, Geophys. Res. Lett., 40, 3693-3697, https://doi.org/10.1002/grl.5067, 2013.

Stocker, T. and Johnsen, S. J.: A minimum thermodynamic model for the bipolar seesaw, Paleoceanography, 18, 1087, https://doi.org/10.1029/2003PA000920, 2003.

Stuiver, M. and Braziunas, T. V.: Modeling atmospheric ${ }^{14} \mathrm{C}$ influences and ${ }^{14} \mathrm{C}$ ages of marine samples to 10,000 B.C., Radiocarbon, 35, 137-189, 1993.

Svensson, A., Andersen, K. K., Bigler, M., Clausen, H. B., DahlJensen, D., Davies, S. M., Johnsen, S. J., Muscheler, R., Parrenin, F., Rasmussen, S. O., Röthlisberger, R., Seierstad, I., Steffensen, J. P., and Vinther, B. M.: A 60000 year Greenland stratigraphic ice core chronology, Clim. Past, 4, 47-57, https://doi.org/10.5194/cp-4-47-2008, 2008.

Sweeney, C., Gloor, E., Jacobson, A. R., Key, R. M., McKinley, G., Sarmiento, J. L., and Wanningkhof, R.: Constraining global air-sea gas exchange for $\mathrm{CO}_{2}$ with recent bomb ${ }^{14} \mathrm{C}$ measurements, Global Biochem. Cy., 21, GB2015, https://doi.org/10.1029/2006GB002784, 2007.

Toggweiler, J. R., Druffel, E. R. M., Key, R. M., and Galbraith, E. D.: Upwelling in the ocean basins north of the ACC. Part 2: How cool Subantarctic water reaches the surface in the tropics, J. Geophys. Res., 124, 2609-2625, https://doi.org/10.1029/2018JC014795, 2019.

Turney, C. S. M., Fifield, L. K., Hogg, A. G., Turney, C. S. M., Fifield, L. K., Hogg, A. G., Palmer, J. G., Bailie, M. G. L., Galbraith, R., Odgen, J., Lorrey, A., Tims, S., and Jones, R. T.: Using New Zealand kauri (Agathis australis) to test the synchronicity of abrupt climate change during the Last Glacial Interval $(60,000-$ 11,700 years ago), Quaternary Sci. Rev., 29, 3677-3682, 2010.

Turney, C. S. M., Jones, R. T., Phipps, S. J., Thomas, Z., Hogg, A., Kershaw, A.P., Fogwill, C. J., Palmer, J., Bronk-Ramsey, C., Adolphi, F., Muscheler, R., Hughen, K. A., Staff, R. A., 
Grosvenor, M., Golledge, N. R., Rasmussen, S. O., Hutchinson, D. K., Haberly, S., Lorrey, A., Boswijk, G., and Cooper, A.: Rapid global ocean-atmosphere response to Southern Ocean freshening during the last glacial, Nat. Commun., 8, 520, https://doi.org/10.1038/s41467-017-00577-6, 2017.

Umling, N. E. and Thunnell, R. C.: Synchronous deglacial thermocline and deep-water ventilation in the eastern equatorial Pacific, Nat. Commun., 8, 14203. https://doi.org/10.1038/ncomms14203, 2017.

Waelbroeck, C., Duplessy, J.-C., Michel, E., Labeyrie, L., Paillard, D., and Duprat, J.: The timing of the last deglaciation in North Atlantic climate records, Nature, 412, 724-727, 2001.

Waelbroeck, C., Skinner, L. C., Labeyrie, L., Duplessy, J.-C., Michel, E., Riveiros, N. V., Gherardi, J.-M., and Dewilde, F.: The timing of deglacial circulation changes in the Atlantic, Paleoceanography, 26, PA3213, https://doi.org/10.1029/2010PA002007, 2011.

WAIS Divide Project Members: Onset of deglacial warming in West Antarctica driven by local orbital forcing, Nature, 500, 440-444, https://doi.org/10.1038/nature12376, 2013.

Wallmann, K., Schneider, B., and Sarnthein, M.: Effects of eustatic sea-level change, ocean dynamics, and nutrient utilization on atmospheric $p \mathrm{CO}_{2}$ and seawater composition over the last 130000 years: a model study, Clim. Past, 12, 339-375, https://doi.org/10.5194/cp-12-339-2016, 2016.

Wang, L. J., Sarnthein, M., Erlenkeuser, H., Grimalt, J., Grootes, P., Heilig, S., Ivanova, E., Kienast, M., Pelejero, C., and Pflaumann, U.: East Asian monsoon climate during the late Pleistocene: High-resolution sediment records from the South China Sea, Mar. Geol., 156, 245-284, 1999.
Wang, P., Clemens, S., Beaufort, L., Braconnot, P., Ganssen, G., Jian, Z., Kershaw, P., and Sarnthein, M.: SCOR/IMAGES Working Group 113 SEAMONS: Evolution and variability of the Asian Monsoon System: State of the art and outstanding issues, Quaternary Sci. Rev., 24, 595-629, 2005.

Wang, Y. C, Cheng, H., Edwards, R. L., An, Z. S., Wu, J. Y., Shen, C.-C., and Dorale, J. A.: A high-resolution absolute-dated Late Pleistocene monsoon record from Hulu Cave, China, Science, 294, 2345-2348. https://doi.org/10.1126/science.1064618, 2001.

Xu, J., Kuhnt, W., Holbourn, A., Regenberg, M., and Andersen, N.: Indo-Pacific Warm Pool variability during the Holocene and Last Glacial Maximum, Paleoceanogr., 25, PA4230, https://doi.org/10.1029/2010PA001934, 2010.

Yamamoto, A., Abe-Ouchi, A., Ohgaito, R., Ito, A., and Oka, A.: Glacial $\mathrm{CO}_{2}$ decrease and deep-water deoxygenation by iron fertilization from glaciogenic dust, Clim. Past, 15, 981-996, https://doi.org/10.5194/cp-15-981-2019, 2019.

Zhao, N. and Keigwin, L. D.: An atmospheric chronology for the glacial-deglacial Eastern Equatorial Pacific, Nat. Commun., 9, 3077, https://doi.org/10.1038/s41467-018-05574-x, 2018.

Zhao, N., Marchal, O., Keigwin, L., Amrhein, D., and Gebbie, G.: A synthesis of deep-sea radiocarbon records and their (in) consistency with modern ocean ventilation, Paleoceanography and Paleoclimatology, 33, 128-151, 2018. 